\title{
Temporal patterns in disparity and diversity of the Jurassic ammonoids of southern Germany
}

\author{
Marc S. Simon ${ }^{1}$, Dieter Korn ${ }^{*}, 1$ and Stefan Koenemann ${ }^{2}$ \\ ${ }^{1}$ Museum für Naturkunde Berlin, Invalidenstraße 43, 10115 Berlin, Germany. E-mail: dieter.korn@mfn-berlin.de \\ ${ }^{2}$ Institute for Animal Ecology and Cell Biology, University of Veterinary Medicine Hannover, Buenteweg 17d, 30559 Hannover, Germany
}

\begin{abstract}
Received 1 May 2010

Accepted 10 September 2010

Published 21 February 2011

\section{Key Words}

\section{Ammonoidea}

Morphometric analyses

Elliptical Fourier Analysis

A morphometric analysis of the characteristic whorl cross-sections of 1,200 Jurassic ammonoid species from southern Germany enabled us to characterise their morphospace. The successive Jurassic ammonoid faunas of southern Germany show characteristic patterns in morphospace occupation. While Early and Middle Jurassic ammonoids occupy limited areas of the morphospace range, the Late Jurassic ammonoids cover the entire spectrum. The ammonoids are characterised by an overall increase of both taxonomic diversity and morphological disparity in the course of the Jurassic. Strong fluctuations occur until the middle Late Jurassic, followed by a diversity decrease in the early Kimmeridgian and a disparity reduction in the early Tithonian. While diversity and disparity show similar progression during most of the Early Jurassic, they diverge subsequently and show only poor correlation until the end of the Jurassic. Particularly in the Middle Jurassic diversity and sea level changes correlate strongly. Neither temporal patterns in diversity nor disparity support the hypothesis of a mass extinction event in the early Toarcian. Significant changes in diversity and disparity in the early Callovian support a putative migration event of Boreal ammonoids into the Tethyan realm.
\end{abstract}

\section{Introduction}

Morphology represents an important tool in descriptive and analytical biology and particularly in palaeontology. Whereas early studies concentrated on qualitative description of morphological characters, there was a transition in the early 20th century leading to analytical approaches with quantitative elements (Thompson 1917; see also Bookstein 1998). This new exploratory focus called morphometrics contained measurement data (metric values, angles etc.) and was introduced '....in order to describe changes in morphological characters and their correlation with other variables' (Adams et al. 2004). Due to the lack of information about morphological characters of a given shape as a whole, a second transition was necessary that focused on shape and occurred in the late 20th century. The establishment of this 'geometric morphometrics', allowed the description of the entire shape of an organism or any part of its skeleton or shell and its geometrical features. This was such a big watershed that Rohlf \& Marcus (1993) felt obliged to call it a 'revolution in morphometrics'. Two major methods are the landmark-based analysis and the outline analysis. The first concentrates largely on homologous points in the shape of morphologically similar individuals (Bookstein 1991) and the second provides differences in the form of shape outlines (Ferson et al. 1985). With the aid of these methods it is possible to outline a morphospace containing a broad spectrum of morphological information representing the entire shape.

A morphospace divided in space and time allows the observer to identify morphological developments and enables them to compare these developments with ecological and environmental circumstances affecting the evolution of organisms. Since Eldredge \& Gould (1972) proposed widespread stasis in fossil taxa, implying alternating phases with different evolution rates, research interest focused more and more on events that evoke such anomalies. Extinction events, which are

* Corresponding author 
normally followed by phases with an immense increase in the rate of evolution, can be considered as causes for huge diversification. According to Hallam \& Wignall (1997) mass extinction events are mostly evoked by climatic changes, which, on their part, can be induced by various causes (mainly volcanism, sea level changes, bolide impacts). Hallam \& Wignall (1997) described mass extinction events as causes for evolutionary dynamics. Besides the 'Big Five' (described by Raup \& Sepkoski 1982), which had an immense influence on many groups of organisms, several smaller mass extinction events, which were mostly limited to a few groups of organisms, took place during Earth's history.

A major aspect of research interest is the relationship of disparity and diversity (e.g. Foote 1993; Wills et al. 1994). Contrary to the widely held belief of a strong correlation, Foote (1993) as well as Moyne \& Neige (2007) discovered oppositional trends, leading to the awareness that both parameters are independent (see also Wills 2001).

As several authors have concentrated on the morphology of Jurassic ammonites (e.g. Neige et al. 1997, 2001; Courville \& Crônier 2005; Navarro et al. 2005; Simon et al. 2010), the research interest of this study is the analysis of morphospace dynamics in ammonoids from southern Germany compared to diversity changes over the Jurassic period. Furthermore, disparity and diversity changes are to be consulted for replication with changes that were postulated for Jurassic environments. Here, the characterization and differentiation of radiation and migration events is an important topic.

In our study we focus upon fluctuations of Jurassic ammonoid morphospace occupation within a geographically defined area (Fig. 1) and the possible causes of these changes. In particular, two postulated Jurassic mass extinction events in the early Toarcian and in the late Tithonian, respectively, described by Hallam (1986) and Hallam \& Wignall (1997), were investigated on the basis of our data.

This study benefits from the improved resolution of the Jurassic time scale that allows us to construct a detailed morphospace series composed of 72 differentiated zones, with each zone averaging $0.75 \mathrm{Ma}$. Furthermore, this study concentrates on ammonite assemblages within a relatively small area (southern Germany), of which the palaeogeographic conditions are well-known. Dommergues et al. (2001) as well as Moyne \& Neige (2007) remarked that research into

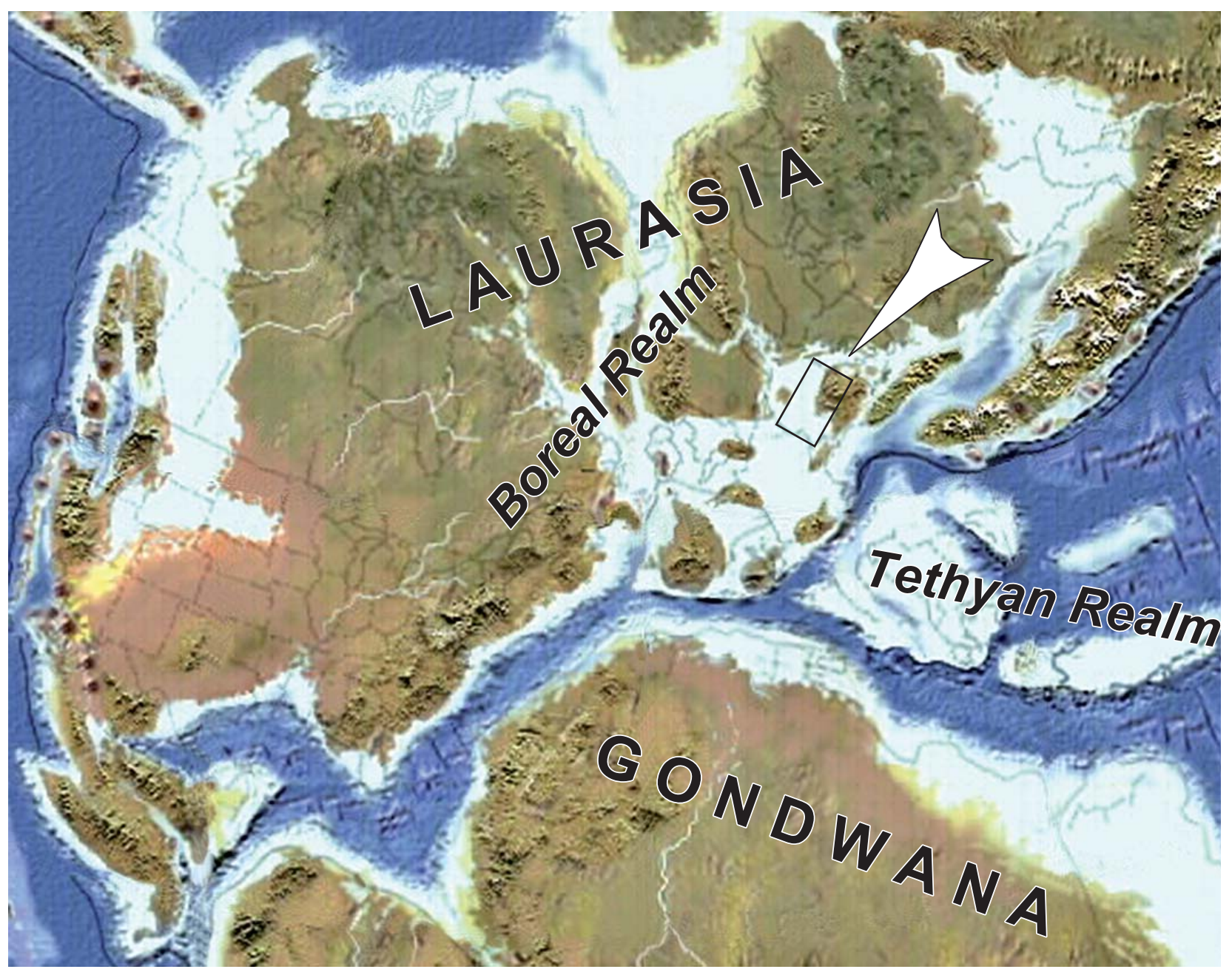

Figure 1. Paleogeographic map of the northern hemisphere for the Middle Jurassic (170 Ma) with underlying shapes of todays country's frontiers. The study area in southern Germany is marked with a rectangle (map from R.C. Blakey; http://jan.ucc.nau.edu). 
large areas with cosmopolitan organisms merely provides vague data sets that are, as in the case of long time intervals, neither able to depict comparatively sudden local events nor able to differ between migration and radiation/extinction events.

Hallam (1986) as well as Hallam \& Wignall (1997) doubted the suitability of ammonoids for such analyses; their very nature as index fossils would make them susceptible to even weak changes, it might be this fact that qualifies them to detect environmental disturbances before other organism groups.

\section{Jurassic environment}

The Jurassic is one of the most intensely investigated periods of the geological record. The stratigraphy and the palaeogeographic patterns of faunas are well known. The resulting stratigraphic subdivision, according to Dean et al. (1961) and Schlegelmilch (1985, 1992, 1994), is shown in Figure 2. It provides an excellent framework for research about causes and processes and patterns of disparity changes in time and space.

The Jurassic distribution of landmasses and epicontinental seas was influenced by the break-up of Pangaea leading to the opening of the North Atlantic Ocean and the disintegration of Laurasia and Gondwana. The progressive continental break-up as well as major sea level changes during the Jurassic caused environmental changes in Central Europe, which was, compared to it's present day latitude located up to $30^{\circ}$ further south (Irving 1964; Hallam 1971).

According to Hallam (1971) the Jurassic European seas can be subdivided into two more or less separate realms, a northern Boreal and a southern Tethyan realm, distinguished by different faunas, with cephalopods as an example. The fact that southern Germany today lies upon the borderline separating these two fossil realms makes it an interesting research area.

The southern German shallow sea of the Early Jurassic was connected with the northern European Boreal region through the 'Hessische Straße' (Hessian Street). In contrast, it had only weak southerly connections to the Tethyan realm as a result of the Vindelician landmasses that largely separated the two marine realms (Kuhn 1953; Geyer \& Gwinner 1986; Walter 1992). During the Middle Jurassic the connection with the Boreal region was closing due to the westward expansion of the Bohemian landmasses; while the disappearance of the southern Vindelician landmasses opened connections with the Tethys Ocean (Geyer \& Gwinner 1986; Walter 1992). In the same interval the boundary between Tethyan and Boreal realms underwent a northward shift leading to the northward migration of Tethyan fauna (Hallam 1971). According to Cecca \& Macchioni (2004) such a migration already took place at the Pliensbachian-Toarcian boundary in combination with a putative mass extinction in the early Toarcian. Vertical zonation of the water masses, e.g. with declin- ing oxygen gradients (detectable in the early Toarcian Posidonienschiefer deposition of southern Germany), may have affected the occurrence of ammonoid species.

Hallam (1993, 1998, 2001) outlined the climatic conditions of the Jurassic. According to his studies the Jurassic period had different climate zones with seasonal temperatures and humidity changes. Sea temperatures within $30{ }^{\circ} \mathrm{C}$ around the equator were above presentday levels indicating tropical conditions. According to Hallam (2001) glacial episodes are not recorded. However, in contrast Dromart et al. (2003) postulated at least one glaciation at the Middle/Late Jurassic boundary accompanied by a global regression as well as extinction and southward migration of marine invertebrate communities.

Two mass extinction events were postulated to occur within the Jurassic period. The first was proposed for the early Toarcian (Hallam 1986, 1996; Hallam \& Wignall 1997; Aberhan \& Fürsich 1996; Aberhan \& Baumiller 2003), when deep-sea anoxia, due to transgression, provoked a worldwide crisis. Cecca \& Macchioni (2004) as well as Dera et al. (2010) described the Pliensbachian/Toarcian mass extinction as a twofold event, linked to a disruption of ammonoid fauna provinciality. The second Jurassic mass extinction occurred at the end of the Tithonian and was probably caused by the preceding end-Jurassic regression (Hallam 1986; Hallam \& Wignall 1997).

In spite of general transgressive trends during the Jurassic (apart from the end-Jurassic regression), Hallam (1996, 1997, 2001) described several small regression events that show some correlations with stage boundaries. According to Hallam (2001) a detectable, maybe global regression paralleled the Aalenian, and a local regression occurred in the Bathonian. Dromart et al. (2003) mention a further regression in the late Callovian.

\section{Material and methods}

The whorl cross-sections for morphometric analyses were taken from the monographic depictions of Schlegelmilch (1985, 1992, 1994), who surveyed data from old monographs such as Quenstedt (1885, 1886, 1888). Our analyses comprised a characteristic adult (often the final) whorl of all species of which sections were illustrated; only a few species could not be considered since the respective outlines were lacking. Illustrations from 1,200 species (368 Early, 418 Middle, and 414 Late Jurassic species) were scanned and then digitized and were then included in the analysis. Further diversity analyses were geared to the taxonomy given by Schlegelmilch $(1985,1992,1994)$.

Outline tracing was conducted, with the tpsdig program (Rohlf 2004), by transforming each outline shape into $500 x / y$-coordinates for the subsequent Elliptical Fourier Analysis (Foote 1989). The software packages used to transform outline data into periodical functions were the programs hangle and hmatch introduced by Crampton \& Haines (1996). In our analysis we used 12 harmonics representing 24 Fourier coefficients.

A principal component analysis (PCA) was performed on the Fourier coefficients (Fig. 3). This was done with the program PAST (Ham- 


\begin{tabular}{|c|c|c|c|c|c|c|}
\hline \multirow{12}{*}{$\begin{array}{c}\text { Age (Ma) } \\
145.5\end{array}$} & $\begin{array}{l}\text { Duration } \\
\text { m.y. }\end{array}$ & Epoch & Stage & $\begin{array}{c}\text { Zones (Quenstedt } \\
1885,1886,1888)\end{array}$ & $\begin{array}{l}\text { Zones (Dean et al. } \\
\text { 1961; Schlegelmilch } \\
\text { 1985, 1992, 1994) }\end{array}$ & $\begin{array}{c}\text { Zone index species (Dean et al. } \\
\text { 1961; Schlegelmilch 1985, } \\
1992,1994)\end{array}$ \\
\hline & \multirow{11}{*}{5.3} & \multirow{28}{*}{$\begin{array}{l}\cdot \frac{\mathcal{U}}{\mathcal{N}} \\
\text { ( } \\
\text { ত্ } \\
3 \\
3\end{array}$} & \multirow{11}{*}{ Tithonian } & & ti 4 & \\
\hline & & & & Weisser Jura Zeta 6b & ti $3 e$ & \multirow{2}{*}{$\begin{array}{c}\text { Isterites palmatus } \\
\text { Pseudolissoceras bavaricum }\end{array}$} \\
\hline & & & & Weisser Jura Zeta $6 a$ & ti 3d & \\
\hline & & & & \multirow{3}{*}{ Weisser Jura Zeta 5} & ti $3 c$ & Danubisphinctes palatinus \\
\hline & & & & & ti $3 b$ & \multirow{4}{*}{ Neochetoceras mucronatum } \\
\hline & & & & & ti $3 a$ & \\
\hline & & & & \multirow{2}{*}{ Weisser Jura Zeta 4} & ti $2 b$ & \\
\hline & & & & & ti $2 \mathbf{a}$ & \\
\hline & & & & Weisser Jura Zeta 3 & ti 1c & Subplanites postrueppellianus \\
\hline & & & & Weisser Jura Zeta 2 & ti 1b & Subplanites rueppellianus \\
\hline & & & & Weisser Jura Zeta 1 & ti 1a & Lithacoceras ulmense \\
\hline \multirow{8}{*}{150.8} & & & & Weisser Jura Epsilon 2 & ki 3c & Virgataxioceras setatum \\
\hline & & & & & ki $3 \mathbf{b}$ & Sutneria subeumela \\
\hline & & & & Weisser Jura Epsilon 1 & ki $3 \mathbf{a}$ & Sutneria pedinopleura \\
\hline & & & & Weisser Jura Delta $3 \& 4$ & ki $\mathbf{2 b}$ & Aulacostephanus eudoxus \\
\hline & 4.9 & & Kimmeridgian & Weisser Jura Delta 1\&2 & ki 2a & Aulacostephanus mutabilis \\
\hline & & & & & ki 1d & Idoceras balderum \\
\hline & & & & Weisser Jura Gamma 3 & ki 1c & Crussoliceras divisum \\
\hline & & & & Weisser Jura Gamma 2 & ki 1b & Ataxioceras hypselocyclum \\
\hline & & & & Weisser Jura Gamma 1 & ki 1a & Sutneria platynota \\
\hline 155.1 & & & & & ox 2b & Sutneria galar \\
\hline & & & & Weisser Jura Beta & ox $2 a$ & Idoceras planula \\
\hline & & & & & ox $1 f$ & Epipeltoceras bimammatum \\
\hline & & & & & ox 1e & Euaspidoceras hypselum \\
\hline & 0.0 & & uxiotulan & Weisser Jura Alpha & ox 1d & Dichotomoceras bifurcatum \\
\hline & & & & & ox 1c & Gregoryceras transversarium \\
\hline & & & & & ox 1b & Cardioceras cordatum \\
\hline 1612 & & & & & ox 1a & Quenstedtoceras mariae \\
\hline 101.2 & & & & & $\mathrm{cl} 3 \mathrm{~b}$ & Quenstedtoceras lamberti \\
\hline & & & & Brauner Jura Zeta & cl 3a & Peltoceras athleta \\
\hline & 35 & & & & $\mathrm{cl} \mathbf{2 b}$ & Erymnoceras coronatum \\
\hline & 0.5 & & callovian & & $\mathrm{cl} 2 \mathrm{a}$ & Kosmoceras jason \\
\hline & & & & & cl 1b & Sigaloceras calloviense \\
\hline & & & & & cl 1a & Macrocephalites macrocephalus \\
\hline 104.1 & & & & & bt 3c & Clydoniceras discus \\
\hline & & & & & bt $\mathbf{3 b}$ & Oxycerites orbis \\
\hline & & & & & bt 3a & Prohecticoceras retrocostatum \\
\hline & 3.0 & $\frac{\pi}{(0)}$ & Bathonian & & bt 2c & Morrisiceras morrisi \\
\hline & & & & Brauner Jura Epsilon & bt 2b & Tulites subcontractus \\
\hline & & つ & & & bt $2 a$ & Procerites progracilis \\
\hline 1677 & & & & & bt 1a & Zigzagiceras zigzag \\
\hline 101.1 & & (1) & & & bj 3c & Parkinsonia parkinsoni \\
\hline & & & & & bj $3 b$ & Garantiana garantiana \\
\hline & & & & & bj $3 a$ & Strenoceras niortense \\
\hline & 3.9 & & Bajocian & Brauner Jura Delta & bj 2 a & Stephanoceras humphriesianum \\
\hline & & & & & bj 1c & Emileia sauzei \\
\hline & & & & Brauner Jura Gamma & bj $1 \mathrm{~b}$ & Witchellia laeviuscula \\
\hline 1716 & & & & & bj $1 \mathrm{a}$ & Hyperlioceras discites \\
\hline 171.0 & & & & & al 2b & Graphoceras concavum \\
\hline & 4.0 & & Aalenian & Brauner Jura Beta & al 2a & Ludwigia murchisonae \\
\hline & 4.0 & & Malemall & & al 1b & Leioceras opalinum \\
\hline 175.6 & & & & Brauner Jura Alpha & al 1a & Leioceras opainum \\
\hline & & & & & tc 2c & Dumortieria levesquei \\
\hline & & & & Schwarzer Jura Zeta & tc $2 b$ & Grammoceras thouarsense \\
\hline & 7.4 & & Toarcian & & tc $2 \mathbf{a}$ & Haugia variabilis \\
\hline & & & & Schwarzer Jura Epsilon & tc 1c & Hildoceras bifrons \\
\hline & & & & & tc $1 b$ & Harpoceras falcifer \\
\hline 183.0 & & & & Schwarzer Jura Delta & tc 1a & Dactylioceras tenuicostatum \\
\hline & & ふ & & & pb 2b & Pleuroceras spinatum \\
\hline & 6.6 & $\bar{\sigma}$ & Pliensbachian & & pb 2a & Amaltheus margaritatus \\
\hline & & & & Schwarzer Jura Gamma & pb 1c & Prodactylioceras davoei \\
\hline & & & & & pb 1b & Tragophylloceras ibex \\
\hline 189.6 & & & & & pb 1a & Uptonia jamesoni \\
\hline & & & & Schwarzer Jura Beta & si 2d & Echioceras raricostatum \\
\hline & & & & & si 2c & Oxynoticeras oxynotum \\
\hline & 6.9 & Ш & Sinemurian & Zwischenlager Schwarzer Jura Alpha/Beta & si $2 b$ & Asteroceras obtusum \\
\hline & & & & & si 2a & Caenisites turneri \\
\hline & & & & Oberer Schwarzer Jura Alpha & si $1 b$ & Arnioceras semicostatum \\
\hline 196.5 & & & & -------- & si 1a & Arietites bucklandi \\
\hline & 31 & & Hettanaian & Mittlerer Schwarzer Jura Alpha & he $2 b$ & Schlotheimia angulata \\
\hline & & & retlanglan & Unterer Schwarzer Jura Alpha & he $2 a$ & Alsatites liassicus \\
\hline & & & & & he 1 & Psiloceras planorbis \\
\hline
\end{tabular}



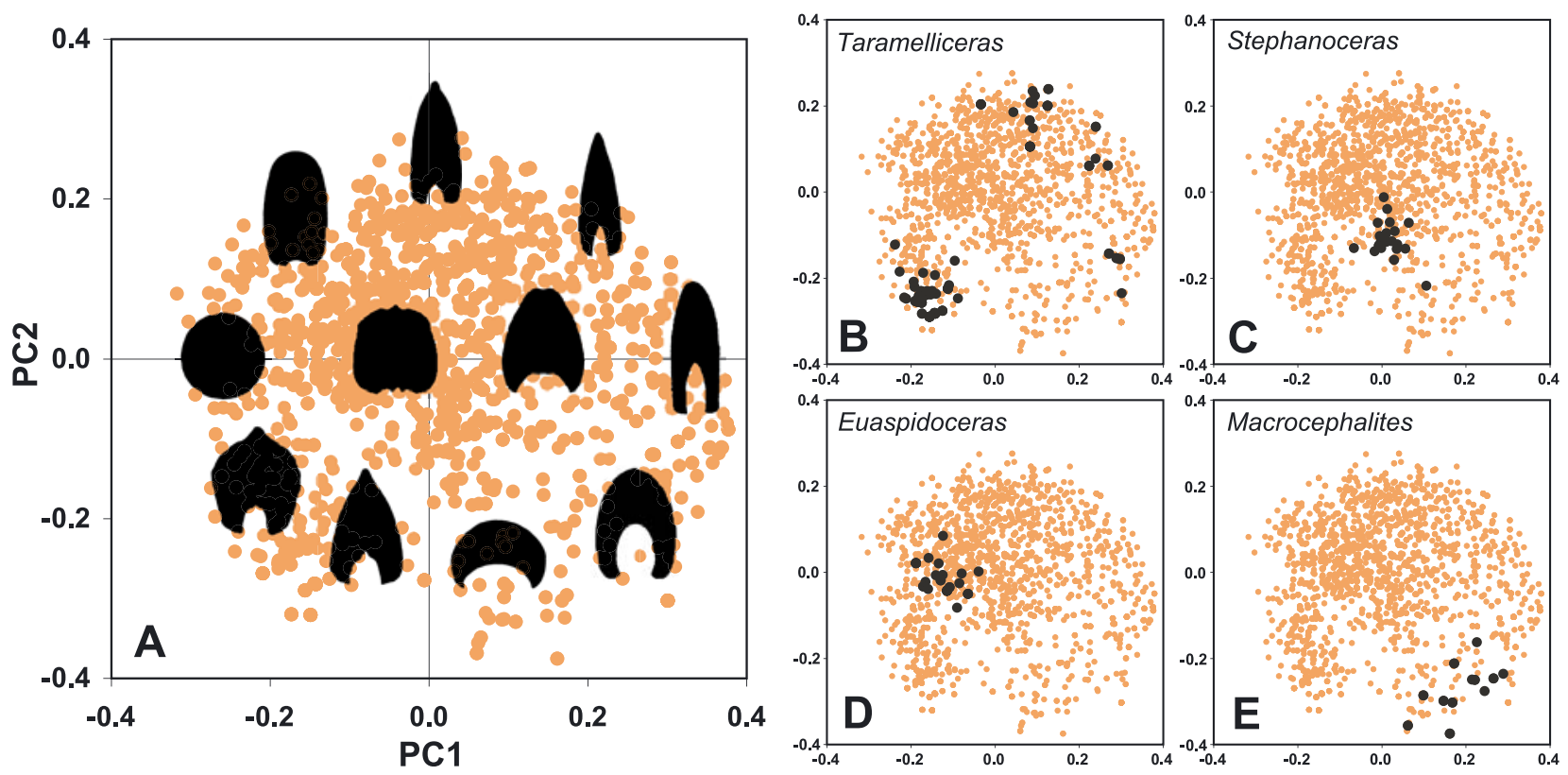

Figure 3. Dispersion of whorl shapes (A) and some selected genera $(\mathbf{B}-\mathbf{E})$ in the morphospace. Note that most members within a genus plot are in a limited area; examples such as Taramelliceras (B) are the exception. From Simon et al. (2010).

mer et al. 2008) using the co-variance algorithm. Of the calculated principal components (PCs), the first three were plotted for each of the 72 stratigraphic zones. Finally, a calculation of quantitative measures illustrates the mathematical relations of the particularly widespread disparity and diversity, as the first describes morphological and the other taxonomical aspects. This was represented by the occurrences of genera and species per zone. In the case of morphological disparity, variance and range of the plotted morphospace were suited for further analysis. Variance is defined as the mean distance between all data points. Range describes the side length of a cube spanning the marginal points of the occupied morphospace.

Quantification of morphospace occupation was achieved by using the first three principal components for each zone to calculate the sum of variance (SOV; the addition of the variances of the first three axes) and sum of range (SOR; the addition of the hypercube side lengths within the first three axes) as described by Wills (2001). Subsampling was conducted in order to receive standardized results. In this case six random data points from each zone were used to repeat the operation 100 times for 71 of 72 zones because of the lacking number of data points in the last zone.

\section{Morphospace of Jurassic ammonoids}

Within the principal component analysis, $79 \%$ of the entire ammonoid whorl section outline variance is explained by the first three axes (PC1 explains $34 \%$, PC2 $25 \%$, and PC3 $20 \%$ ). In order to depict a threedimensional scatter plot the coordinate axes $\mathrm{PC} 1 / \mathrm{PC} 2$ and $\mathrm{PC} 1 / \mathrm{PC} 3$ were used for further analyses (Fig. 4).

Across some zonal boundaries SOV and SOR change markedly, while others are not accompanied by con- spicuous changes (Fig. 5A). Some of the Early and Middle Jurassic transitions between zones show extreme fluctuations, which sometimes seem to be linked to the appearance/disappearance of taxa in marginal positions of the morphospace. These data points represent the appearance of strikingly new morphologies, possibly caused by immigration.

Directional and non-directional changes of morphospace arrangement in combination with SOV, SOR, and the centroid position (i.e. the mean position of all morphospace data points) provide a well resolved picture of the temporal changes of ammonoid morphology relating to whorl cross sections. According to the results of Simon et al. (2010) we can distinguish three major modes of morphospace development that can occur between two adjacent zones:

1. Morphospace stasis accompanied by SOR with no or minor changes, respectively, whereas SOV and diversity may differ insignificantly.

2. Morphospace widening by heightening of the SOR. This may be connected with an increasing SOV (morphospace inflation through occupation of the margins), stable SOV (randomly distributed entries) or decreasing SOV (predominant occupation of the morphospace centre). Significant changes in morphospace centroid may indicate immigration instead of radiation.

3. Morphospace reduction by lowering of the SOR. Again, the SOV can increase (either extinction with

Figure 2. Classification of zones within Jurassic stratigraphy, time scale according to Gradstein \& Ogg (2004). Southern German zones according to Quenstedt $(1885,1886,1888)$. Zonal scheme and zone index species according to Dean et al. (1961) and Schlegelmilch $(1985,1992,1994)$. Abbreviations: he = Hettangian, si = Sinemurian, $\mathrm{pb}=$ Pliensbachian, $\mathrm{tc}=$ Toarcian, $\mathrm{al}=$ Aalenian, $\mathrm{bj}=$ Bajocian, $\mathrm{bt}=$ Bathonian, $\mathrm{cl}=$ Callovian, $\mathrm{ox}=$ Oxfordian, $\mathrm{ki}=$ Kimmeridgian, $\mathrm{ti}=$ Tithonian. 

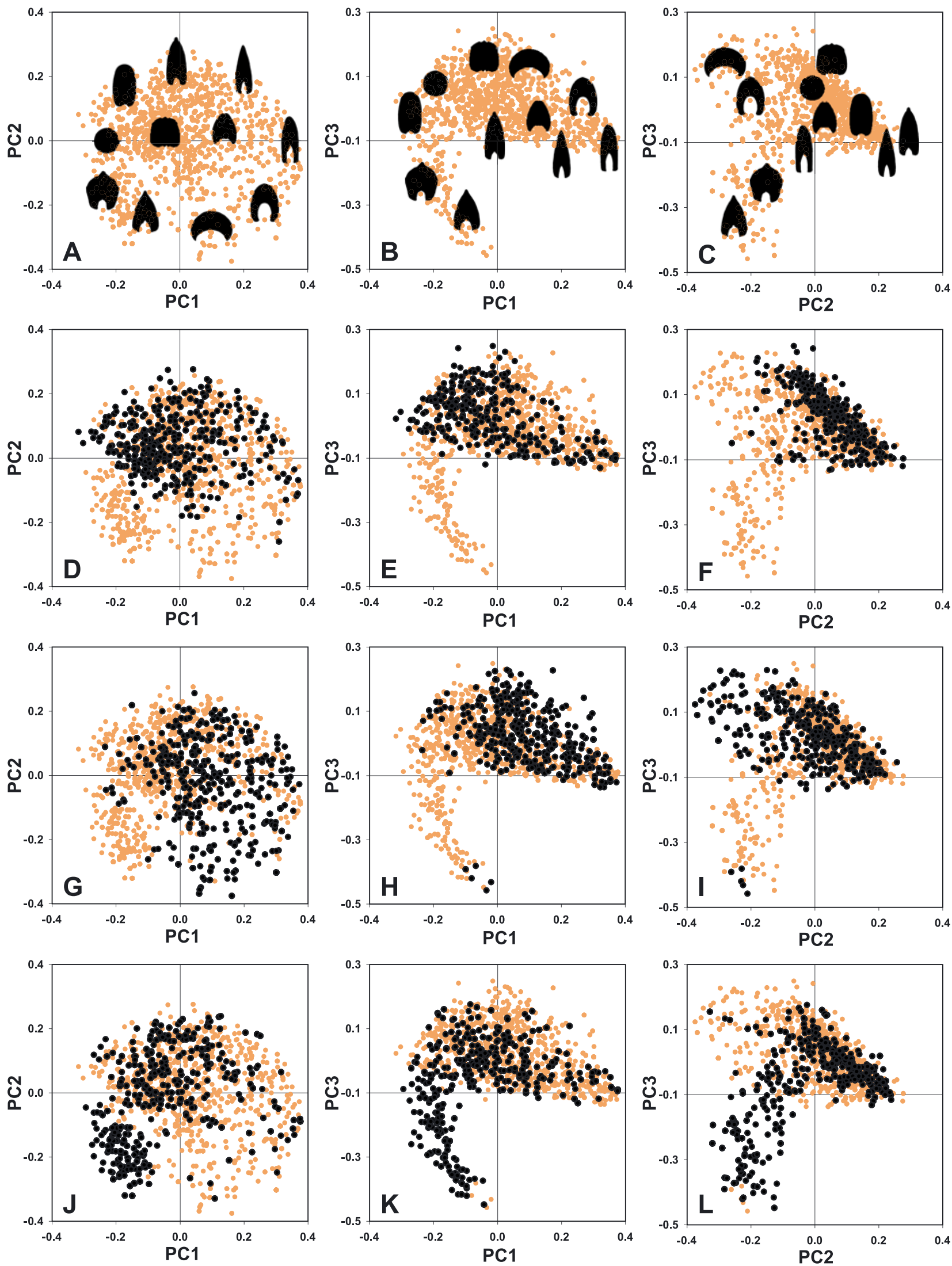

Figure 4. Morphospace of 1,200 Jurassic ammonoid species from southern Germany with diagrams for PC1/PC2 on the left, for PC1/PC3 in the middle and for PC1/PC3 on the right side. Examples of cross section are shown in A-C; accentuated data points mark occurring species in the Early $(\mathbf{D}-\mathbf{F})$, Middle $(\mathbf{G}-\mathbf{I})$ and Late Jurassic $(\mathbf{J}-\mathbf{L})$. From Simon et al. (2010). 


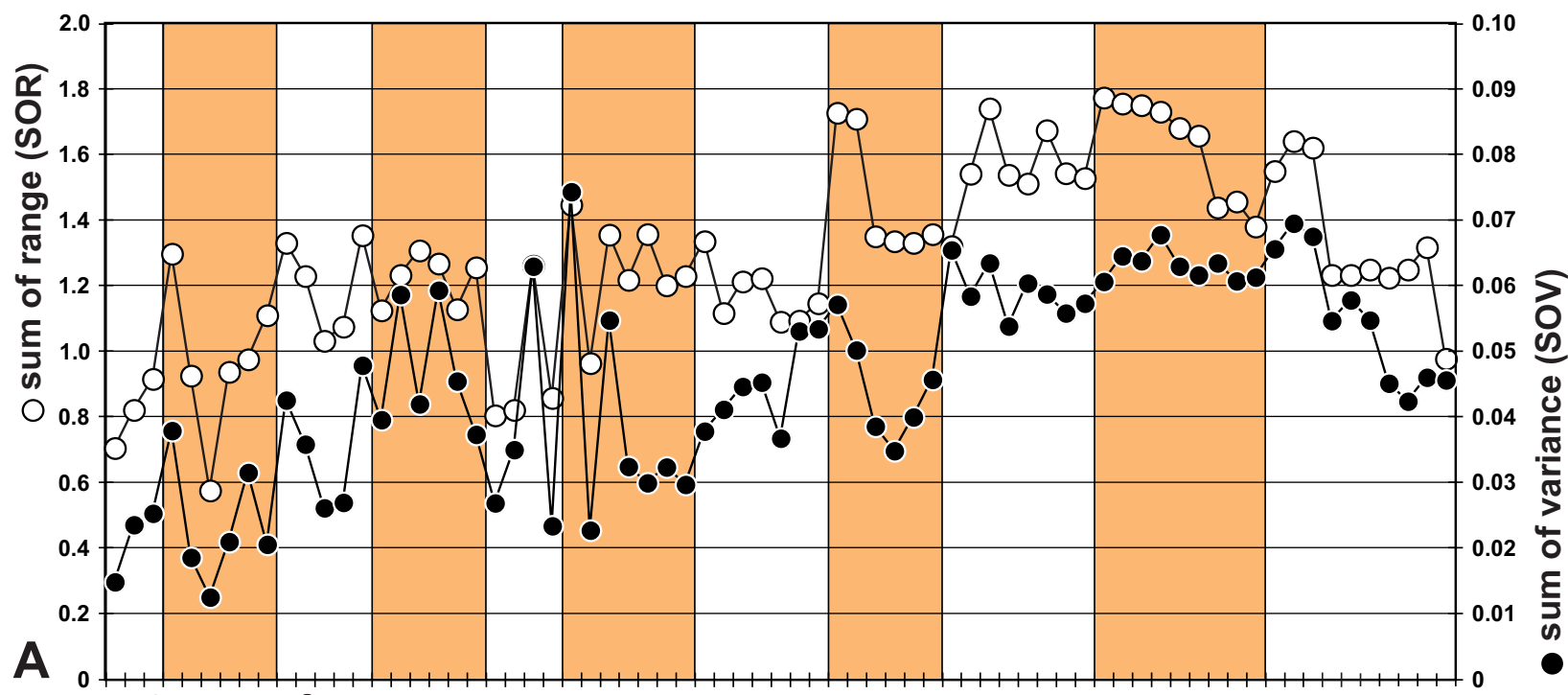

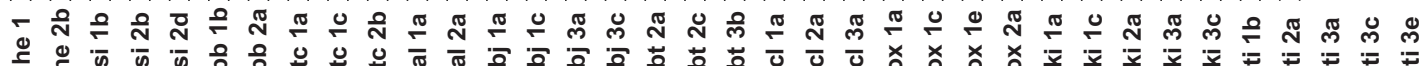

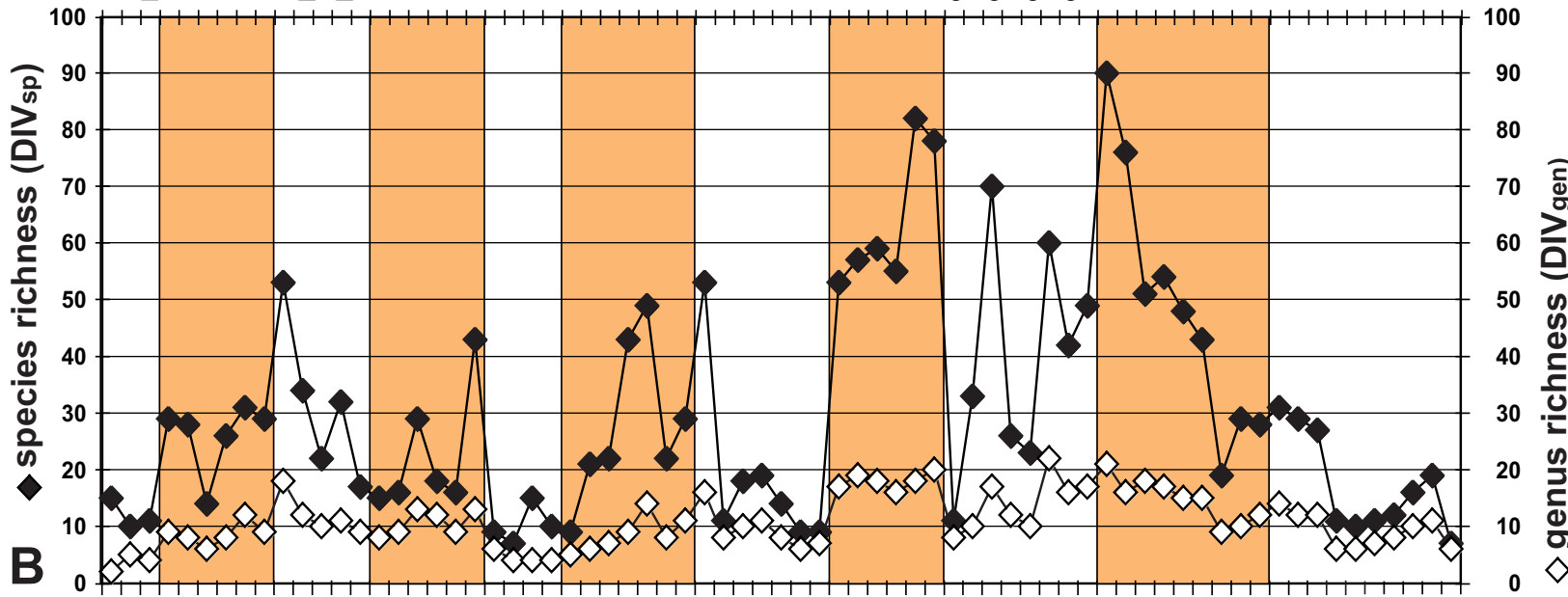

Figure 5. Patterns of disparity and diversity of Jurassic ammonoids from southern Germany. A. Sum of variance (SOV) and sum of range $(\mathrm{SOR})$, B. Species richness $\left(\mathrm{DIV}_{\mathrm{sp}}\right)$ and genus richness $\left(\mathrm{DIV}_{\mathrm{gen}}\right)$.

selection on the morphospace centre or a two-folded event of extinction and following occupation in different morphospace positions), stagnate (non-selective extinction or migration) or decrease (selective extinction by trimming of the margins). Here it is hardly possible to distinguish between extinction and migration events.

The scatter plots of the first three principal components show characteristic patterns for each of the three Jurassic epochs. Comparing the outline shapes with occupied areas it can be observed that changes in PC1 determine the imprint ratio of whorls. Increasing PC1 leads to more involute outlines as can be seen best in the diagram PC1/PC3 (Fig. 4B). While the Early and Middle Jurassic taxa tend to occupy positions in a restricted area (apart from few data points certain areas of the possible morphospace are not occupied) the Late Jurassic scatter plot ranges the entire spectrum of the morphospace (Fig. 4). The morphospace generally tends to disperse over the Jurassic period while the respective focal point differs. Especially the gradually increasing occupation of the morphospace, at values with negative PC1 and PC3, indicates a trend in morphospace occupation. While Middle Jurassic ammonoids just show sporadic approaches towards such morphs, ammonoids in the Late Jurassic already have such shapes integrated successfully in their morphology spectrum.

Subsampling of the disparity parameters reveals disparity curves that show similar progression to the nonstandardized data (Fig. 6). The SOR generally provides lower values than the raw data. Differences between raw and subsampled data in the SOV are weak apart from a smoothing of strong fluctuations. This indicates a dependence of the SOR, at least in small samples, and an apparent independence of the SOV on the sample size. However, both parameters show large error bars that overlap to a large extent. This fact qualifies the results and complicates interpretation. Nevertheless, we used SOV raw data as main parameter for disparity analysis. 

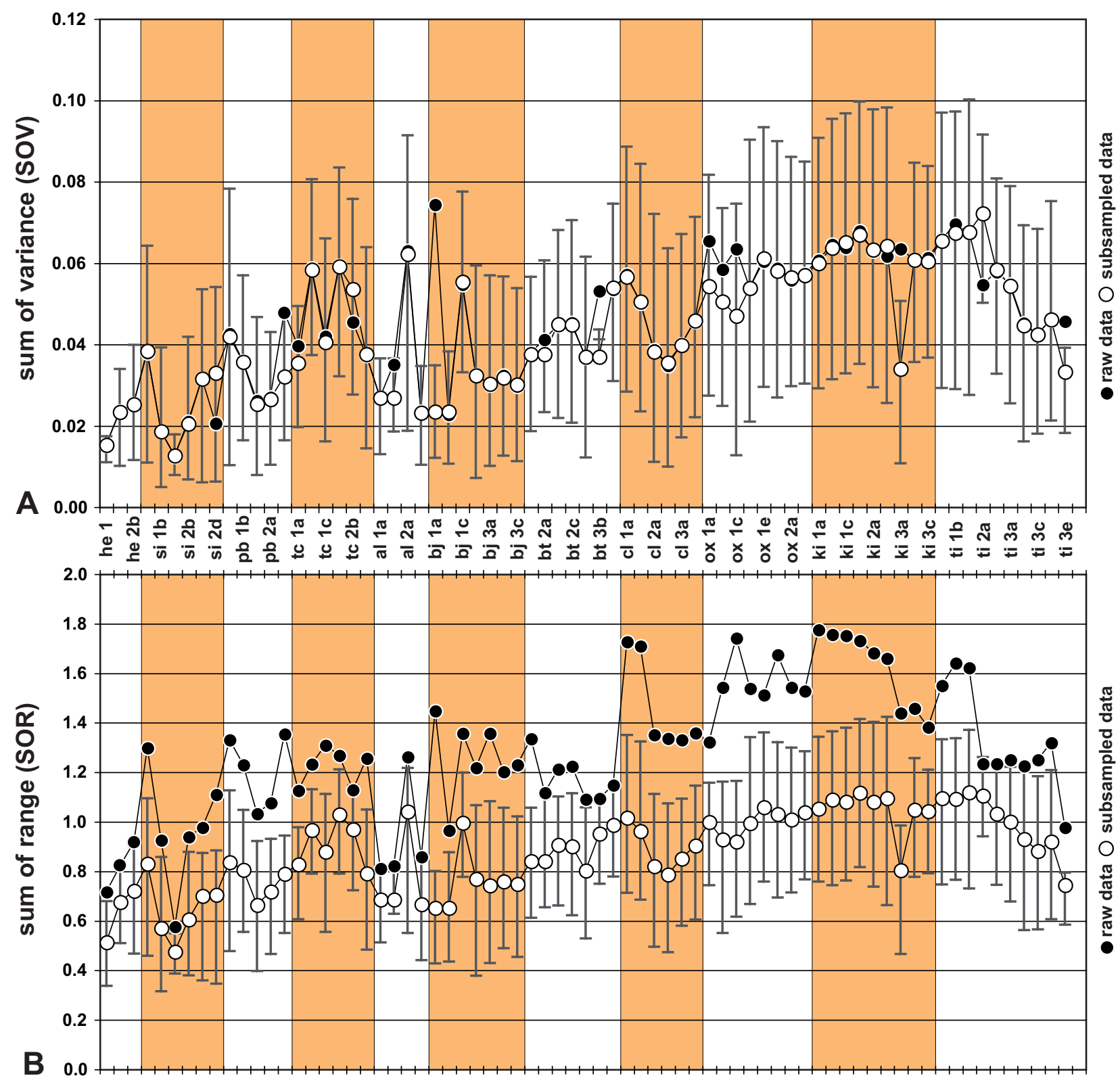

Figure 6. Subsampling results of disparity. Data are rarified 1,000 times to a set of 6 taxa, error bars cover $95 \%$ confidence intervals. A. Raw and subsampled data of the sum of variance (SOV); B. Raw and subsampled data of the sum of range (SOR).

\section{Dynamics of disparity and diversity}

Comparison of scatter plot areas and whorl shapes shows that general trends of morphospace occupation are detectable. Similar species mostly plot together as well (Fig. 3).

During most of the Early Jurassic, at least up to the early Pliensbachian, diversity and disparity both show a general increase (Fig. 5). However, during the Middle Sinemurian, there is a brief, marked dip in diversity and disparity, followed by a strong increase with its peak in the early Pliensbachian. Diversity and disparity diverge in the late Pliensbachian and do not show successive correlation at all.

In the subsequent course of the Jurassic, disparity is characterised by intermittent strong fluctuations. These are notable from the Toarcian to the Bajocian, but sudden decreases at the Toarcian/Aalenian boundary, in the al $2 \mathrm{~b}$ zone as well as the bj $1 \mathrm{~b}$ zone are very conspicuous. Afterwards, disparity (both SOV and SOR) shows irregular but moderate increase until the end of the Callovian. The Late Jurassic contains less disparity changes than the former epochs. During the Oxfordian and Kimmeridgian the SOV is located on a high-level plateau phase. A last peak at the beginning of the Tithonian is followed by a general decrease until the end of the Jurassic.

Genus diversity and species diversity show strong correlation in the course of the Jurassic (Fig. 5B). During the Middle Jurassic diversity correlates conspicuously with sea level changes as described by Hallam (2001). Regression phases (Aalenian, Bathonian) coin- 
Table 1. Diversity and disparity values for 72 Jurassic zones; zonal scheme according to Dean et al. (1961) and Schlegelmilch $(1985,1992,1994)$. Abbreviations: $\mathrm{DIV}_{\mathrm{sp}}=$ species diversity, $\mathrm{D}_{\mathrm{DIV} s p(\mathrm{P})}=$ difference in species diversity in percent, $\mathrm{DIV}_{\text {gen }}=$ genus diversity, $\mathrm{D}_{\mathrm{DIVgen}(\mathrm{P})}=$ difference in genus diversity in percent, $\mathrm{SOR}=$ sum of range, $\mathrm{D}_{\mathrm{SOR}(\mathrm{P})}=$ difference in the sum of range in percent, $\mathrm{SOV}=$ sum of variance, $\mathrm{D}_{\mathrm{SOV}(\mathrm{P})}=$ difference in the sum of variance in percent.

\begin{tabular}{|c|c|c|c|c|c|c|c|c|}
\hline zones & DIV $_{s p}$ & $D_{\text {DIVsp(P) }}$ & $\mathrm{DIV}_{\text {gen }}$ & $D_{\text {DIVgen }(P)}$ & SOR & $D_{S O R(P)}$ & SOV & $D_{\text {sov(P) }}$ \\
\hline he 1 & 15 & & 2 & & 0.705 & & 0.015 & \\
\hline he $2 a$ & 10 & -33 & 5 & 150 & 0.822 & 17 & 0.024 & 60 \\
\hline he $2 b$ & 11 & 10 & 4 & -20 & 0.917 & 12 & 0.025 & 4 \\
\hline si la & 29 & 164 & 9 & 125 & 1.298 & 42 & 0.038 & 52 \\
\hline si $1 b$ & 28 & -3 & 8 & -11 & 0.926 & -29 & 0.019 & -50 \\
\hline si $2 a$ & 14 & -50 & 6 & -25 & 0.577 & -38 & 0.013 & -32 \\
\hline si $2 b$ & 26 & 86 & 8 & 33 & 0.938 & 63 & 0.021 & 62 \\
\hline si $2 c$ & 31 & 19 & 12 & 50 & 0.977 & 4 & 0.032 & 52 \\
\hline si $2 d$ & 29 & -6 & 9 & -25 & 1.110 & 14 & 0.021 & -34 \\
\hline $\mathrm{pb} 1 \mathrm{a}$ & 53 & 83 & 18 & 100 & 1.330 & 20 & 0.043 & 105 \\
\hline $\mathrm{pb} 1 \mathrm{~b}$ & 34 & -36 & 12 & -33 & 1.230 & -8 & 0.036 & -16 \\
\hline $\mathrm{pb} 1 \mathrm{c}$ & 22 & -35 & 10 & -17 & 1.033 & -16 & 0.026 & -28 \\
\hline $\mathrm{pb} 2 \mathrm{a}$ & 32 & 45 & 11 & 10 & 1.076 & 4 & 0.027 & 4 \\
\hline $\mathrm{pb} 2 \mathrm{~b}$ & 17 & -47 & 9 & -18 & 1.354 & 26 & 0.048 & 78 \\
\hline tc $1 a$ & 15 & -12 & 8 & -11 & 1.125 & -17 & 0.040 & -17 \\
\hline tc $1 b$ & 16 & 7 & 9 & 13 & 1.232 & 10 & 0.059 & 48 \\
\hline tc $1 c$ & 29 & 81 & 13 & 44 & 1.308 & 6 & 0.042 & -29 \\
\hline tc $2 a$ & 18 & -38 & 12 & -8 & 1.268 & -3 & 0.059 & 40 \\
\hline tc $2 b$ & 16 & -11 & 9 & -25 & 1.128 & -11 & 0.045 & -24 \\
\hline tc $2 c$ & 43 & 169 & 13 & 44 & 1.256 & 11 & 0.037 & -18 \\
\hline al 1a & 9 & -79 & 6 & -54 & 0.805 & -36 & 0.027 & -27 \\
\hline al $1 b$ & 7 & -22 & 4 & -33 & 0.822 & 2 & 0.035 & 30 \\
\hline al 2a & 15 & 114 & 4 & 0 & 1.261 & 53 & 0.063 & 80 \\
\hline al $2 b$ & 10 & -33 & 4 & 0 & 0.858 & -32 & 0.023 & -63 \\
\hline bj 1a & 9 & -10 & 5 & 25 & 1.447 & 69 & 0.074 & 222 \\
\hline bj $1 b$ & 21 & 133 & 6 & 20 & 0.964 & -33 & 0.023 & -69 \\
\hline bj $1 c$ & 22 & 5 & 7 & 17 & 1.356 & 41 & 0.055 & 139 \\
\hline bj 2a & 43 & 95 & 9 & 29 & 1.218 & -10 & 0.032 & -42 \\
\hline bj 3a & 49 & 14 & 14 & 56 & 1.357 & 11 & 0.030 & -6 \\
\hline bj $3 b$ & 22 & -55 & 8 & -43 & 1.202 & -11 & 0.032 & 7 \\
\hline bj $3 c$ & 29 & 32 & 11 & 38 & 1.230 & 2 & 0.030 & -6 \\
\hline bt 1a & 53 & 83 & 16 & 45 & 1.335 & 9 & 0.038 & 27 \\
\hline bt 2a & 11 & -79 & 8 & -50 & 1.118 & -16 & 0.041 & 8 \\
\hline bt $2 b$ & 18 & 64 & 10 & 25 & 1.213 & 8 & 0.045 & 10 \\
\hline bt $2 c$ & 19 & 6 & 11 & 10 & 1.223 & 1 & 0.045 & 0 \\
\hline bt 3a & 14 & -26 & 8 & -27 & 1.090 & -11 & 0.037 & -18 \\
\hline bt $3 b$ & 9 & -36 & 6 & -25 & 1.093 & 0 & 0.053 & 43 \\
\hline bt $3 c$ & 9 & 0 & 7 & 17 & 1.147 & 5 & 0.053 & 0 \\
\hline cl 1a & 53 & 489 & 17 & 143 & 1.727 & 51 & 0.057 & 8 \\
\hline $\mathrm{cl} 1 \mathrm{~b}$ & 57 & 8 & 19 & 12 & 1.710 & -1 & 0.050 & -12 \\
\hline $\mathrm{cl} 2 \mathrm{a}$ & 59 & 4 & 18 & -5 & 1.351 & -21 & 0.039 & -22 \\
\hline $\mathrm{cl} 2 \mathrm{~b}$ & 55 & -7 & 16 & -11 & 1.336 & -1 & 0.035 & -10 \\
\hline cl 3a & 82 & 49 & 18 & 13 & 1.330 & 0 & 0.040 & 14 \\
\hline $\mathrm{cl} 3 \mathrm{~b}$ & 78 & -5 & 20 & 11 & 1.358 & 2 & 0.046 & 15 \\
\hline ox 1a & 11 & -86 & 8 & -60 & 1.322 & -3 & 0.065 & 41 \\
\hline $0 \times 1 b$ & 33 & 200 & 10 & 25 & 1.542 & 17 & 0.058 & -11 \\
\hline $0 \times 1 c$ & 70 & 112 & 17 & 70 & 1.742 & 13 & 0.063 & 9 \\
\hline ox $1 d$ & 26 & -63 & 12 & -29 & 1.538 & -12 & 0.054 & -14 \\
\hline
\end{tabular}


Table 1. Continued

\begin{tabular}{|c|c|c|c|c|c|c|c|c|}
\hline zones & DIV $_{s p}$ & $D_{\text {DIVsp }(P)}$ & DIV $_{\text {gen }}$ & $D_{\text {DIVgen }(P)}$ & SOR & $D_{S O R}(P)$ & SOV & $D_{\text {SOV }}(\mathrm{P})$ \\
\hline ox $1 \mathrm{e}$ & 23 & -12 & 10 & -17 & 1.512 & -2 & 0.060 & 11 \\
\hline ox $1 f$ & 60 & 161 & 22 & 120 & 1.674 & 11 & 0.059 & -2 \\
\hline $0 \times 2 a$ & 42 & -30 & 16 & -27 & 1.543 & -8 & 0.056 & -5 \\
\hline$o \times 2 b$ & 49 & 17 & 17 & 6 & 1.528 & -1 & 0.057 & 2 \\
\hline ki la & 90 & 84 & 21 & 24 & 1.774 & 16 & 0.061 & 7 \\
\hline ki $1 b$ & 76 & -16 & 16 & -24 & 1.757 & -1 & 0.065 & 7 \\
\hline ki $1 \mathrm{c}$ & 51 & -33 & 18 & 13 & 1.751 & 0 & 0.064 & -2 \\
\hline ki $1 d$ & 54 & 6 & 17 & -6 & 1.731 & -1 & 0.068 & 6 \\
\hline ki 2a & 48 & -11 & 15 & -12 & 1.682 & -3 & 0.063 & -7 \\
\hline ki $2 b$ & 43 & -10 & 15 & 0 & 1.659 & -1 & 0.062 & -2 \\
\hline ki 3a & 19 & -56 & 9 & -40 & 1.439 & -13 & 0.064 & 3 \\
\hline ki 3b & 29 & 53 & 10 & 11 & 1.458 & 1 & 0.061 & -5 \\
\hline ki 3c & 28 & -3 & 12 & 20 & 1.381 & -5 & 0.061 & 0 \\
\hline ti $1 a$ & 31 & 11 & 14 & 17 & 1.550 & 12 & 0.066 & 8 \\
\hline ti $1 b$ & 29 & -6 & 12 & -14 & 1.641 & 6 & 0.070 & 6 \\
\hline ti $1 c$ & 27 & -7 & 12 & 0 & 1.622 & -1 & 0.068 & -3 \\
\hline ti $2 a$ & 11 & -59 & 6 & -50 & 1.234 & -24 & 0.055 & -19 \\
\hline ti $2 b$ & 10 & -9 & 6 & 0 & 1.234 & 0 & 0.058 & 5 \\
\hline ti $3 a$ & 11 & 10 & 7 & 17 & 1.250 & 1 & 0.055 & -5 \\
\hline ti $3 b$ & 12 & 9 & 8 & 14 & 1.225 & -2 & 0.045 & -18 \\
\hline ti $3 c$ & 16 & 33 & 10 & 25 & 1.250 & 2 & 0.042 & -7 \\
\hline ti $3 d$ & 19 & 19 & 11 & 10 & 1.319 & 6 & 0.046 & 10 \\
\hline ti $3 e$ & 7 & -63 & 6 & -45 & 0.977 & -26 & 0.046 & 0 \\
\hline ti 4 & 1 & -86 & 1 & -83 & - & & - & \\
\hline
\end{tabular}

cide with low diversity, whereas more species occur during stages showing transgressive tendencies (Bajocian, Callovian). Strong fluctuations in the Oxfordian and the subsequent decrease from the Kimmeridgian and Tithonian characterise the Late Jurassic.

\section{Discussion of morphospace development}

The total SOV spans values between 0.013 (si 2a) and 0.074 (bj 1a) (Table 1). In addition, SOR values range from 0.58 (si 2a) to 1.77 (ki 1a). The number of genera and species ranges from 1 to 22 and from 1 to 83 , respectively, per zone. According to the SOV values there are six different phases that classify the Jurassic period:

1. Nearly the entire Early Jurassic shows a general increase of morphological variance and partially strong fluctuations (SOV range $=0.013-0.059$ ).

2. A decrease of the SOV at the end of the Early Jurassic causes a low disparity at the beginning of the Middle Jurassic with strong fluctuations in the Aalenian and Bajocian (SOV ranging between 0.023 and 0.074).

3. An almost constant increase characterises the disparity curve during the second half of the Middle Jurassic until the early Callovian (SOV range $=0.030-$ 0.057).
4. A temporal decrease during the Callovian interrupts the long-term increase of disparity in the Middle Jurassic (SOV range $=0.035-0.050$ ).

5. The Oxfordian and Kimmeridgian show a continuation of variance at high level (SOV range $=0.054$ 0.068).

6. A slight increase and the following decline towards a moderately low value (SOV $\sim 0.045)$ is detectable in Tithonian disparity (SOV range $=0.042-0.070$ ).

\section{Early Hettangian-late Toarcian}

After the end-Triassic mass extinction, possibly triggered by global regression (Hallam 1996, 1997, 2001; Hallam \& Wignall 1997), only two genera (Neophyllites, Psiloceras) have been found to be present in the first Jurassic zone (he 1 ; SOV $=0.015$ ). This faunal turnover may have its origin in a transgression beginning at the Jurassic (Geyer \& Gwinner 1986; Hallam 2001). Due to the absence of the species-rich genus Psiloceras and its replacement by other (species-poor) genera in the subsequent zones the species diversity decreases in the course of the Hettangian (Schlegelmilch 1992), whereas genus diversity and disparity increase (he $2 \mathrm{a}$; SOV $=0.024$ ). Thus an initial recovery of ammonoid faunas after the $\mathrm{T} / \mathrm{J}$ event can be seen in diversity and disparity. Similar results are given by Dom- 


\section{Sinemurian si 1a}
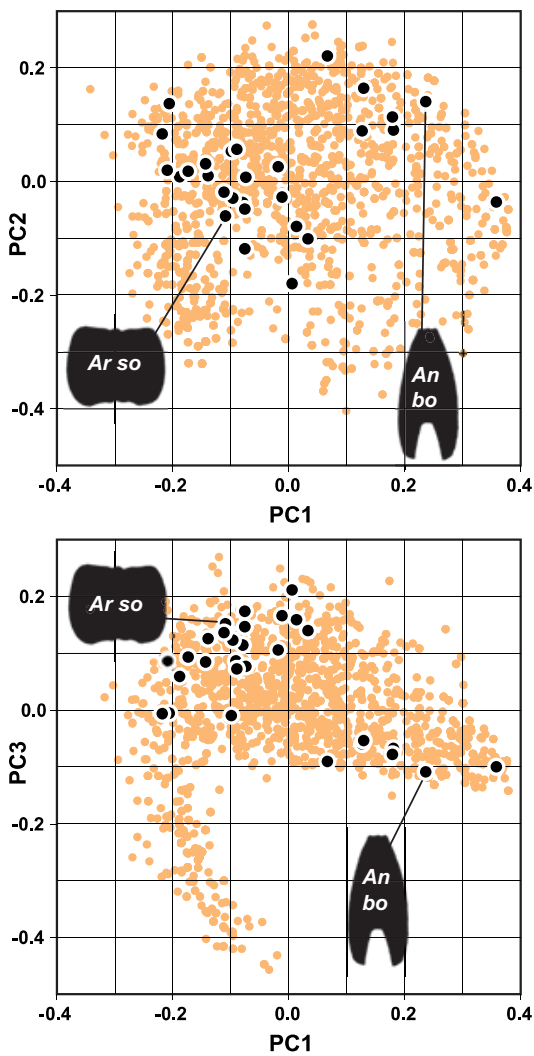

Sinemurian si $1 \mathrm{~b}$
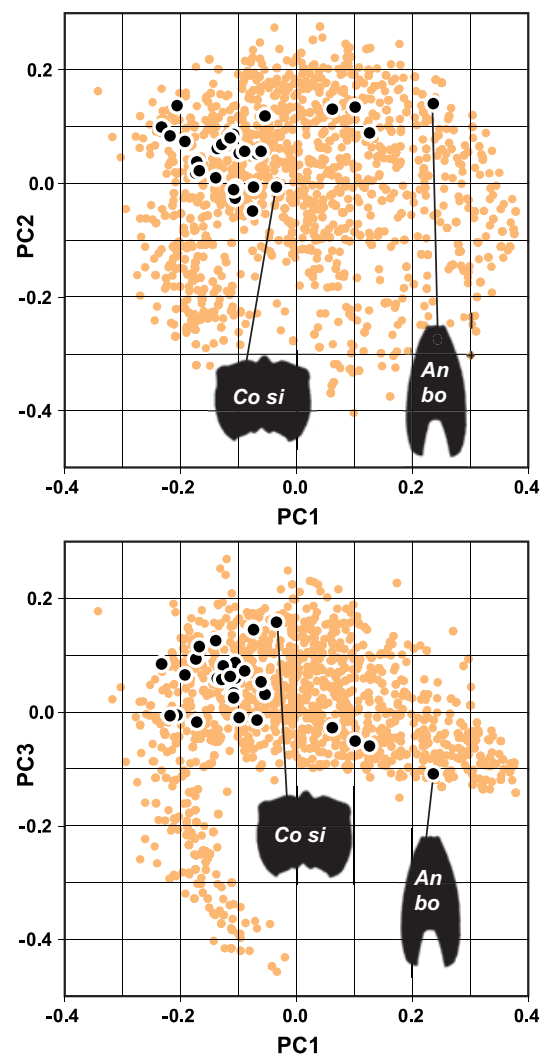

Sinemurian si $2 a$
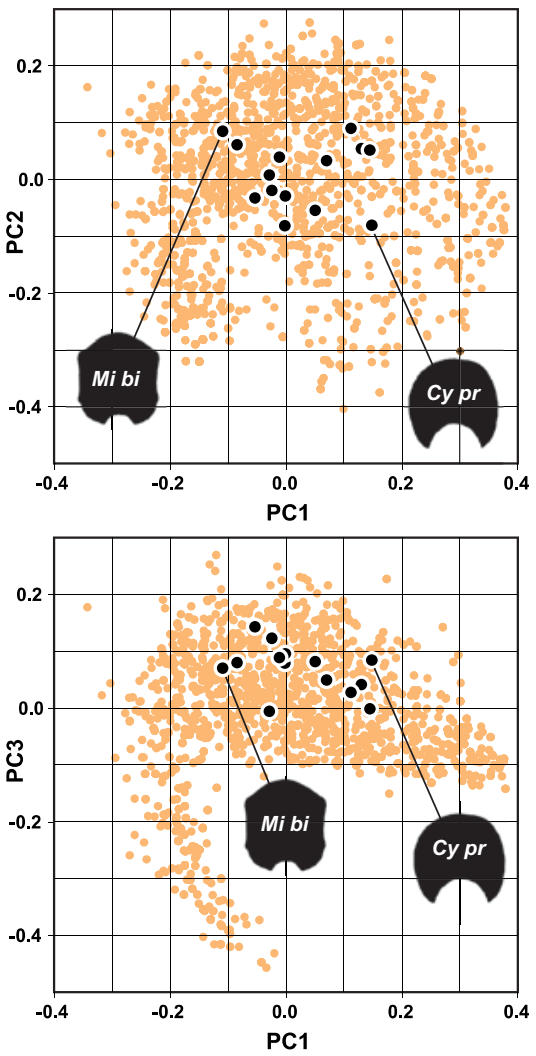

Figure 7. Morphospace development between the three successive Sinemurian zones si 1a, si 1b, and si $2 \mathrm{a}$ from two views (PC1/ PC2 upper diagrams; PC1/PC3 lower diagrams). Ammonoids of the discrete zones are highlighted with the overall morphospace occupation in the background. Whorl outlines with representative shapes are pictured. Abbreviations: An bo = Angulaticeras boucaultianum, Ar so = Arnioceras solarium, $\mathbf{C o} \mathbf{s i}=$ Coroniceras sinemuriense, $\mathbf{C y} \mathbf{p r}=$ Cymbites primus, $\mathbf{M i} \mathbf{b i}=$ Microderoceras birchi.

mergues et al. (1996) and Dommergues et al. (2002), which concentrated on conch morphology and size, respectively.

The increase of disparity in the early Sinemurian si la zone $(\mathrm{SOV}=0.038)$ is caused by the separation of the previously closely clustered morphospace occupation into two distinct fields (Fig. 7). Despite remarkable changes in SOR and centroid position this separation can be considered as a disruptive evolutionary process because of the diversification of the persistent genus Angulaticeras within the segregated smaller cluster. This cluster generation indicates complex patterns of morphospace recovery (see Dommergues et al. 1996).

Rapid trimming of the morphospace margins and the aggregation of the two separated clusters leads to significant decrease in diversity and disparity in the zone si $1 \mathrm{~b}$ and continuing into zone si $2 \mathrm{a} \quad(\mathrm{SOV}=0.013$; Figs 5, 6). The remaining small cluster can be interpreted as a 'stabilising selection' towards 'average morphologies' caused by a hitherto unknown event. An initiation of oxyconic conch shapes during the late $\mathrm{Si}$ nemurian involves the recovery of disparity and diversity ( si 2c; SOV $=0.032$ ).

The Sinemurian-Pliensbachian transition is characterised by a strong increase in both diversity and disparity (pb 1a; SOV $=0.043$ ); here the number of genera doubles. Lytoceratids and phylloceratids occur for the first time in the Jurassic sediments of southern Germany (Schlegelmilch 1992). Some genera reappear in the Pliensbachian after an absence in previous stratigraphic zones. These absences can be explained by immigration events, rather than by gaps in the fossil record, due to the combined appearance of new and Lazarus taxa within the same time interval. In spite of the proceeding transgression (Geyer \& Gwinner 1986; Hallam 2001) variance and diversity drop down in the further course of the Pliensbachian. From the zone $\mathrm{pb} 2 \mathrm{~b}$ on, diversity and disparity diverge and show no further correlation for the later intervals of the Jurassic.

During the Toarcian variation in conch morphology generally increases. Slight fluctuations in disparity are recorded; these are caused by variation of particular regions that are occupied in the morphospace (Fig. 8). After a decrease at the Pliensbachian-Toarcian boundary, diversity values stagnate in the early Toarcian at low levels before a two-fold increase occurs in the second half of the stage. The subsequent strong decrease in diversity marks the boundary between the Early and Middle Jurassic. The similar occupation of morphospace directly after this event is suggestive of a random extinction or migration (Fig. 9). Anyway, no directed development can be observed in our data. 


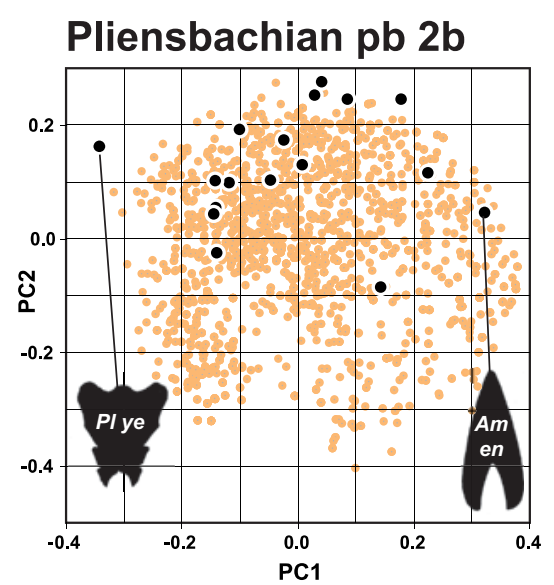

\section{Toarcian tc 1a}
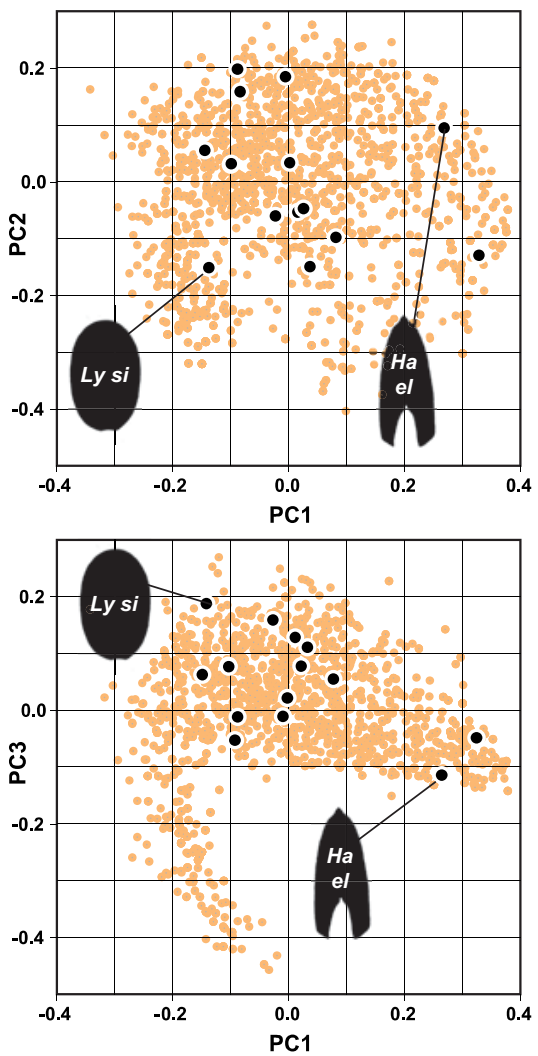

\section{Toarcian tc $\mathbf{1 b}$}
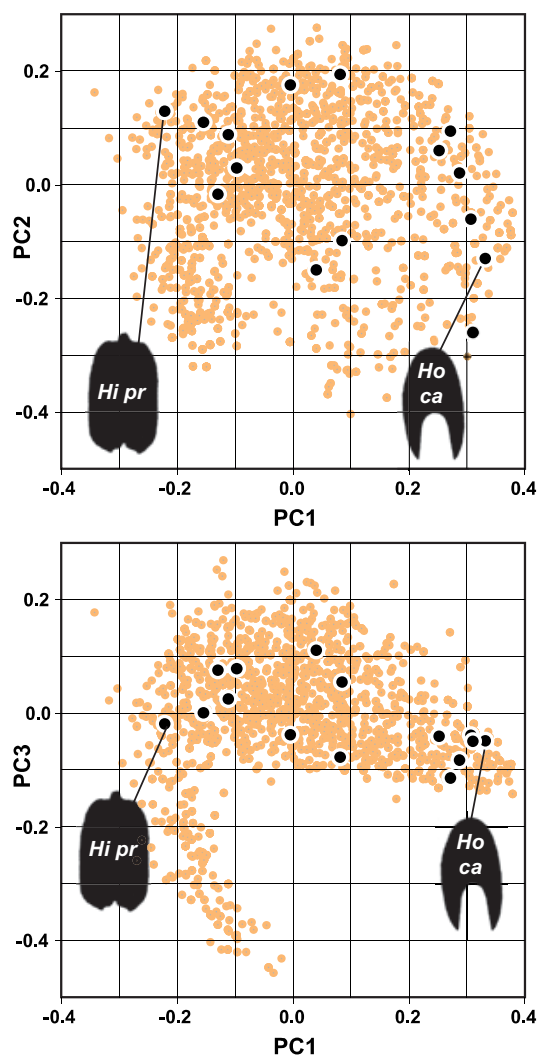

Figure 8. Morphospace development between the three successive zones pb 2b, tc 1a, and tc $1 \mathrm{~b}$ from two views (PC1/PC2 upper diagrams; PC1/PC3 lower diagrams) with the overall morphospace in the background. Whorl outlines with representative shapes are pictured as well. Abbreviations: Am en = Amaltheus engelhardti, Ha el = Harpoceras elegans, Hi pr = Hildoceras propeserpentinum, Ho ca = Holcophylloceras calypso, Ly si $=$ Lytoceras siemensi, $\mathbf{P l} \mathbf{y e}=$ Pleuroceras yeovilense .

No evidence can be found in our disparity and diversity data for the postulated early Toarcian mass extinction event (Hallam 1986, 1996; Hallam \& Wignall 1997; Aberhan \& Fürsich 1996; Aberhan \& Baumiller 2003); only the fluctuation of variance with a nearly unchanged number of species is detectable at the beginning of the Toarcian. A conspicuous decrease of species diversity directly follows the preceding increase at the Sinemurian-Pliensbachian boundary and persists, apart from a small increase in the zone pb $2 \mathrm{a}$, throughout the entire Pliensbachian (Fig. 5B). This fact agrees with the results of Cecca \& Macchioni (2004), who stated an earlier occurrence of the mass extinction than in the early Toarcian but, however, not at the beginning of the Pliensbachian. The high resolution data of Dera et al. (2010) provide similar results as well. A possible explanation could be the general sensitivity of ammonoids towards environmental changes as mentioned by Hallam (1986) and Hallam \& Wignall (1997). Compared to more tolerant organisms, ammonoids would respond earlier to ecological crises. If there is no correlation between those occurrences, the Early Jurassic mass extinction appears to be an event that either affected only benthic organisms or did not take place in the northern Tethyan Ocean.

\section{Early Aalenian-middle Bajocian}

The short period between the early Aalenian and the early Bajocian is characterised by a low level disparity and diversity with very strong fluctuations in the SOV. A first slight upward trend of disparity can be seen in the zone al 1b when first morphospace clusters emerge (Fig. 9). The highest variance value of the Jurassic (bj 1a; SOV =0.074) can be seen in this interval. Disparity has already decreased in the last zone of the Toarcian (tc $2 \mathrm{c}$; SOV $=0.037$ ) and is caused by a diversity increase leading to an accumulation of morphospace points in a narrower area. A drastically decreasing diversity at the transition between the Early and Middle Jurassic accompanies a further decrease in disparity. The disparity curve of the late Aalenian and Bajocian fluctuates enormously between very high (bj 1a; $\quad$ SOV $=0.023$ ) and very low (bj 1b; $\mathrm{SOV}=0.074$ ) levels (Fig. 5, Tab. 1). These discrepancies occur as a result of low diversity in this period allowing huge disparity changes by exchanging only few data points that partially plot together or show wide-ranging distances. 

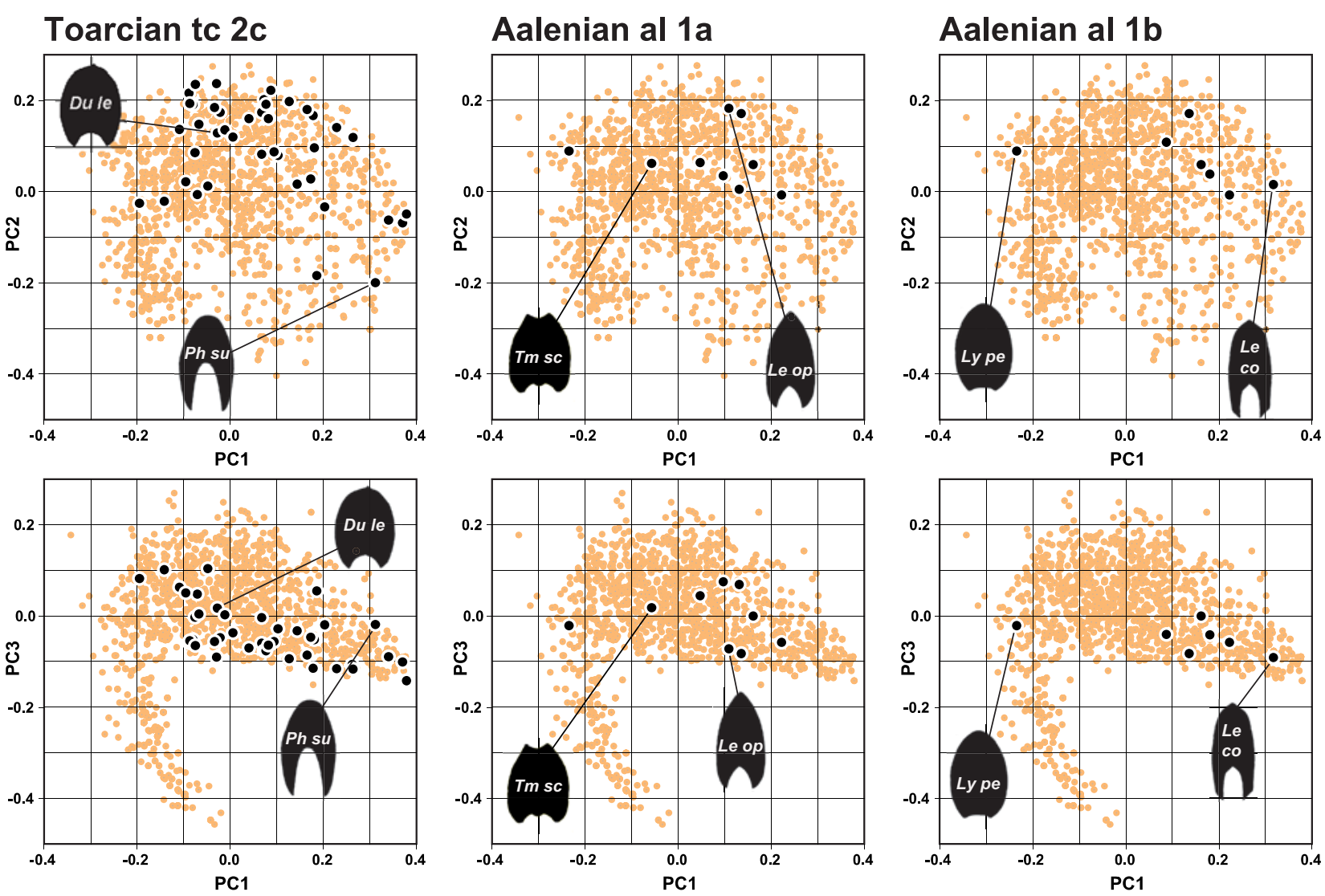

Figure 9. Morphospace development between the three successive Sinemurian zones tc 2c, al 1a, and al 1b from two views (PC1/ PC2 upper diagrams; PC1/PC3 lower diagrams). Ammonoids of the discrete zones are highlighted with the overall morphospace occupation in the background. Whorl outlines with representative shapes are pictured. Abbreviations: Du le $=$ Dumortieria leves$q u e i$, Le co $=$ Leioceras comptum, Le op $=$ Leioceras opalium, Ly pe $=$ Lytoceras penicillatum, $\mathbf{P h} \mathbf{s u}=$ Phylloceras supraliasicum, $\mathbf{T m} \mathbf{s c}=$ Tmetoceras scissum.

\section{Late Bajocian-early Callovian}

A nearly continuous increase is recordable in the disparity curve between the zones bj $3 \mathrm{c}$ and $\mathrm{cl} 1 \mathrm{a}$ (SOV range $=0.030-0.057$ ). Apart from minor fluctuations during the Bajocian the only notable decline is located in the Bathonian zone bt $3 \mathrm{a}(\mathrm{SOV}=0.037)$. The main reason for this decline may be a trimming of the morphospace margins by the, occasionally temporary, loss of morphologically extreme genera (e.g. Oxycerites).

Unlike the relatively consistent disparity curve, diversity continues to fluctuate during this period. The aforementioned correlation between diversity and sea level development accounts for the high, but fluctuating number of species in the Bajocian. A temporary peak is reached in the first zone of the Bathonian (bt 1a). Afterwards a strong decrease leads to low diversity values throughout the rest of the Bathonian. The subsequent rise of the species numbers at the Bathonian-Callovian boundary is the strongest in the Jurassic.

\section{Callovian}

The Callovian represents, in diversity as well as in disparity, a special case. The variance shows only insignif- icant increase at the Bathonian-Callovian transition but during the Callovian stage there is a significant decline of SOV, which is not compensated until the end of the Callovian (SOV range in the Callovian $=0.035-0.057$ ). This decline interrupts the general increase of disparity during the entire Middle Jurassic.

Furthermore, the SOR increases significantly at the Bathonian-Callovian boundary (from 1.15 to 1.73; Fig. 5), which is caused by an extension of taxa into previously unoccupied morphospace areas (Fig. 10). In fact species diversity for this time period shows the strongest increase within the Jurassic period. The genus diversity doubles and the species diversity quintuples between the Bathonian and Callovian. Diversity reaches a high level in the Callovian evoked by two phases of increase. This fast rise in species numbers in combination with increasing SOR can be explained by an immigration of Boreal ammonoid taxa into the Tethyan Realm as described by Thierry (2003) and Navarro et al. (2005). In all likelihood, the decline of SOV during the Callovian is mainly caused by strong diversification within the genus Hecticoceras leading to an accumulation of similar morphospace points. Another reason appears to be the disappearance of the morphologically isolated genus Oxycerites (discoidal forms; Schlegelmilch 1985). 

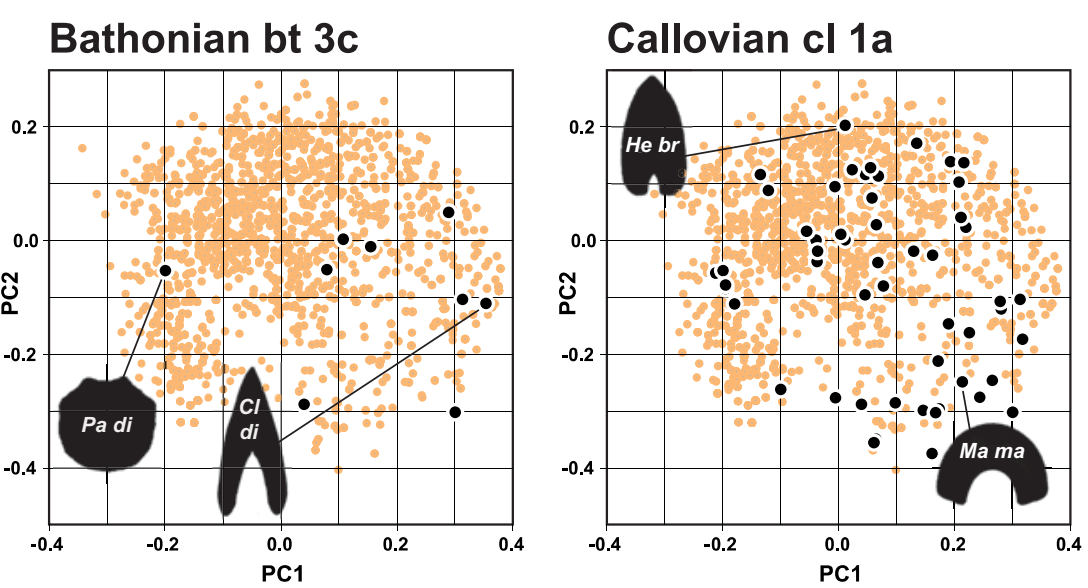

\section{Callovian cl 1b}
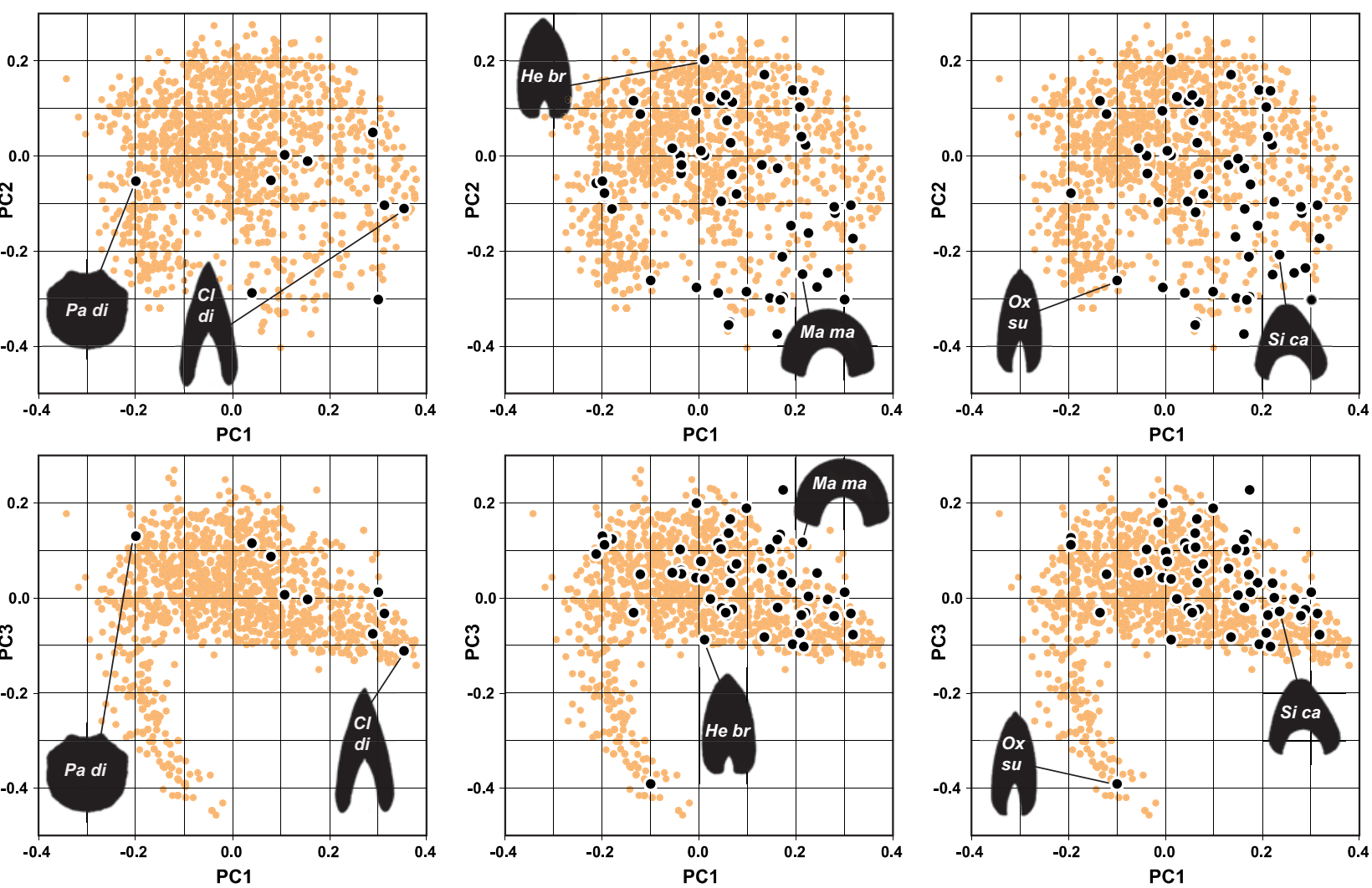

Figure 10. Morphospace development between the three successive zones bt 3c, cl 1a, and cl 1b from two views (PC1/PC2 upper diagrams; PC1/PC3 lower diagrams) with the overall morphospace in the background. Whorl outlines with representative shapes are pictured as well. Abbreviations: Cl di =Clydoniceras discus, He br = Hecticoceras brightii, Ma ma=Macrocephalites

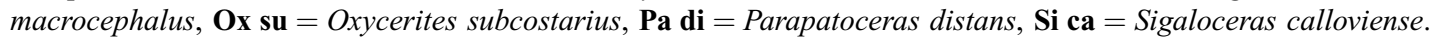

Migration events affected the disparity and diversity values, particularly in the early Callovian. This interpretation contradicts some of the results of Dromart et al. (2003), who postulated a first southward migration of ammonoids at the Callovian-Oxfordian boundary. In our study no evidence was found for such a phase. In contrast, the decreasing diversity at the Callovian-Oxfordian boundary documents a lack of ammonoid species at the beginning of the Late Jurassic (Fig. 5B). Furthermore, according to Schlegelmilch (1985) subboreal and boreal ammonoids are already abundant in the early Callovian (e.g., Kepplerites, $\mathrm{Ca}$ doceras) of southern Germany. It is possible that the overall immigration of boreal species was a multiple event that, however, already began in the early Callovian.

\section{Early Oxfordian-late Kimmeridgian}

The Late Jurassic begins with a significant decline of the taxonomic diversity, with the strongest overall decrease in species numbers at the Callovian-Oxfordian boundary. Here the number of genera falls from 20 to 8 and the number of species from 78 to 11 . Four of these taxa appear, in the basal Oxfordian, in previously unoccupied areas of the morphospace, indicating changes of the environment and possible immigrations. The morphospace of the Late Jurassic ammonoids shows some peculiarities; previously unoccupied areas are now filled quickly in the PC1/PC3 scatter plot, where positions with negative values in both axes are occupied to a large extent in the early Oxfordian (Fig. 11). The most common character that is shared by the members of these morphs is an offset keel at the external side of the conch. This character appears in several taxonomic groups.

The SOV increases rather rapidly at the CallovianOxfordian transition and keeps persisting around the high value 0.060 with only slight fluctuations until the early Tithonian. This high-level disparity is the consequence of the occupation of new marginal morphospace areas of the Late Jurassic ammonoids, with the result of larger relative distances between the few data points in zone ox 1a.

The Oxfordian ammonoids show a general increase but also very strong fluctuations in their diversity, in some cases between two successive zones (e.g. ox 1c-ox d, ox 1e-ox 1f; Fig. 5B). Although slight fluctuations can also be seen in the SOV during the Oxfordian (ranging between 0.054 and 0.065 ) variance remains largely stable. This stability in combination with the strong diversity fluctuation indicates that environmental interferences were non-selective and affected all kinds of am- 
Callovian cl $3 b$
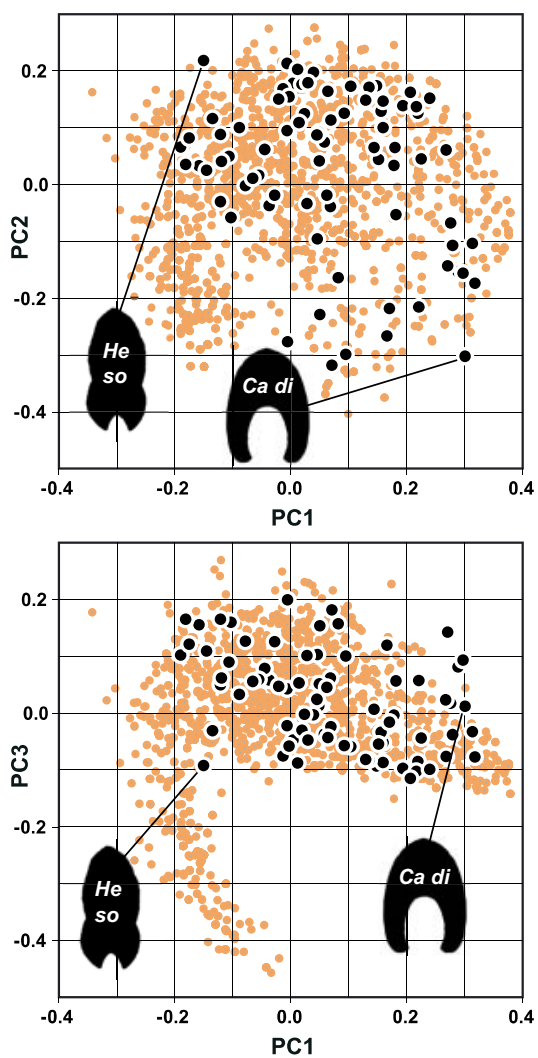

Oxfordian ox 1a

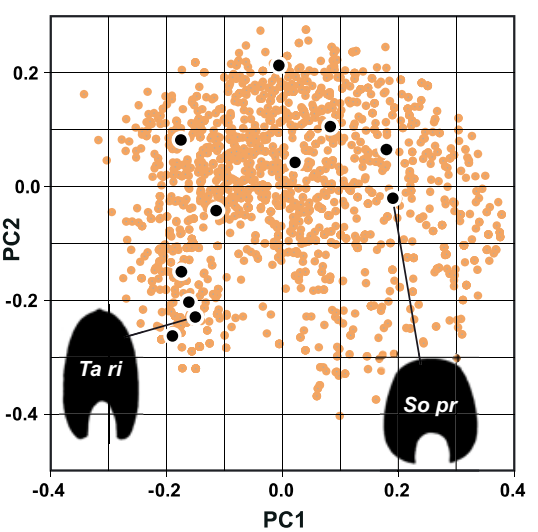

PC1

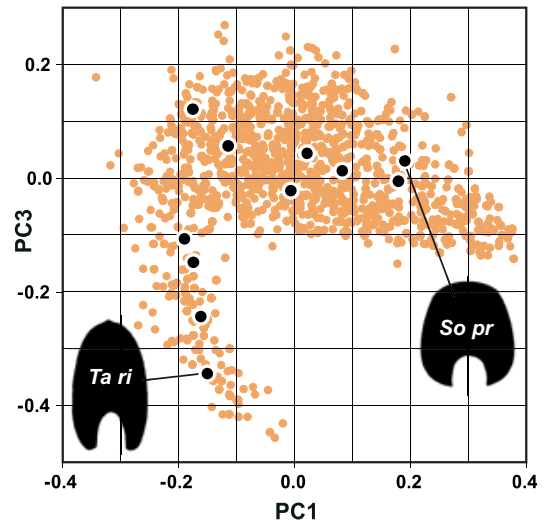

Oxfordian ox 1b
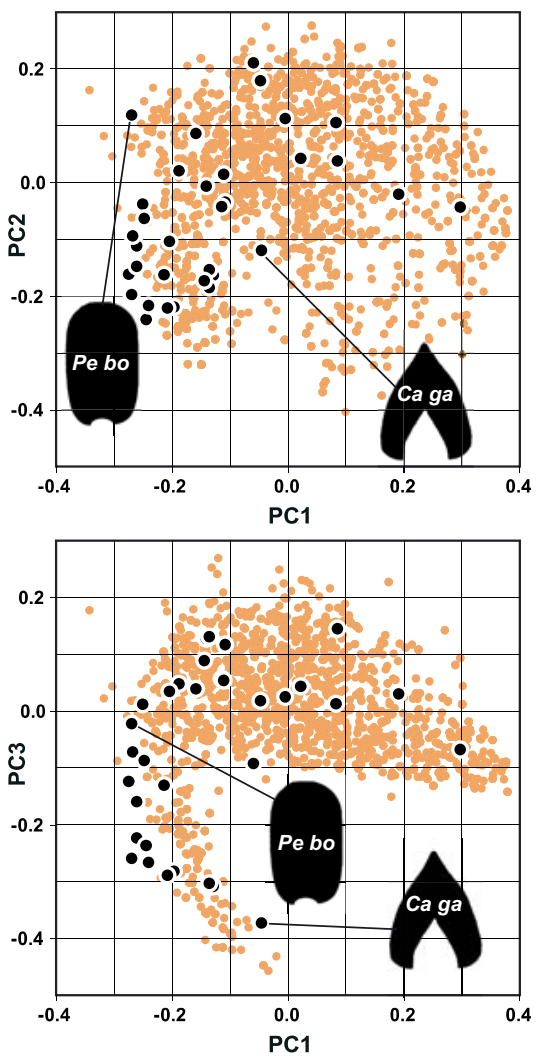

Figure 11. Morphospace development between the successive zones $\mathrm{cl} 3 \mathrm{~b}$, ox 1a, and ox $1 \mathrm{~b}$ depicted from two views (PC1/PC2 upper diagrams; PC1/PC3 lower diagrams). Ammonoids of the respective zones are illustrated with the overall morphospace in the background. Whorl outlines with representative shapes are pictured as well. Abbreviations: Ca di $=$ Calliphylloceras disputabile, Ca ga $=$ Cardioceras gallicum, He so $=$ Hecticoceras solinophorum, Pe bo $=$ Perisphinctes bouranensis, So pr $=$ Sowerbyceras protortisulcatum, Ta ri $=$ Taramelliceras richei.

monoids in similar magnitude. In summary the Oxfordian is a stage where the taxonomic diversity was affected to a great extent.

The Kimmeridgian begins with a peak of taxonomic diversity in zone ki 1a with 90 species, which is the highest number for one zone within the entire Jurassic. In the course of the Kimmeridgian a strong diversity decrease results in 19 species in zone ki 3a. This decrease, which continues into the Tithonian, does not proceed continuously but in two main intervals (Fig. 5B), thereof two in the Kimmeridgian. The first step already begins in the zone ki $1 \mathrm{~b}$ and leads to a reduction in species numbers of almost a half of the previous number. Although disparity values remain stable (SOV ranging between 0.061 and 0.068) the morphospace shape changes in a peculiar way when the former scatter plot is split into three more or less separated clusters, which can be seen in the zone ki 1c (Fig. 12). This indicates speciation processes.

The second interval of decrease takes place between the zones ki 2a and ki 3a. Here the three still existent clusters of ammonoid morphology are similarly affected, which leads to a total disappearance of the smallest one. This pattern suggests that the reason for this decline was non-selective. The successive slight increase of diversity results in the combination of the two remaining clusters. During the last two Kimmeridgian zones, a slight recovery of diversity can be recorded.

\section{Tithonian}

At the beginning of the Tithonian the SOV increases because of an equal and broad scattering of morphospace points until it reaches the maximum disparity in the zone ti $1 \mathrm{~b}(\mathrm{SOV}=0.070)$. The subsequent decrease of disparity (SOV $\sim 0.045$ ) accompanies the third interval of decrease in diversity. The equal decrease in all morphospace areas indicates again a non-selective extinction. Afterwards the remaining small scatter plot slightly expands over the following next four zones involving an increase of the genus and species number at the same time before the fourth decrease leads to the final decline of diversity.

Missing taxonomic data for the last zone (ti 4) and accordingly for the entire late Tithonian prevents the possibility of a detailed disparity analysis. As a result it is impossible to discuss a putative second mass extinction event in the late Tithonian as postulated by Hallam (1986) and Hallam \& Wignall (1997). Up to now, only one ammonoid species (Haploceras elimatum Oppel, 1865; Schlegelmilch 1994) is known from the zone ti 4. The overall decrease of the ammonoid diversity 

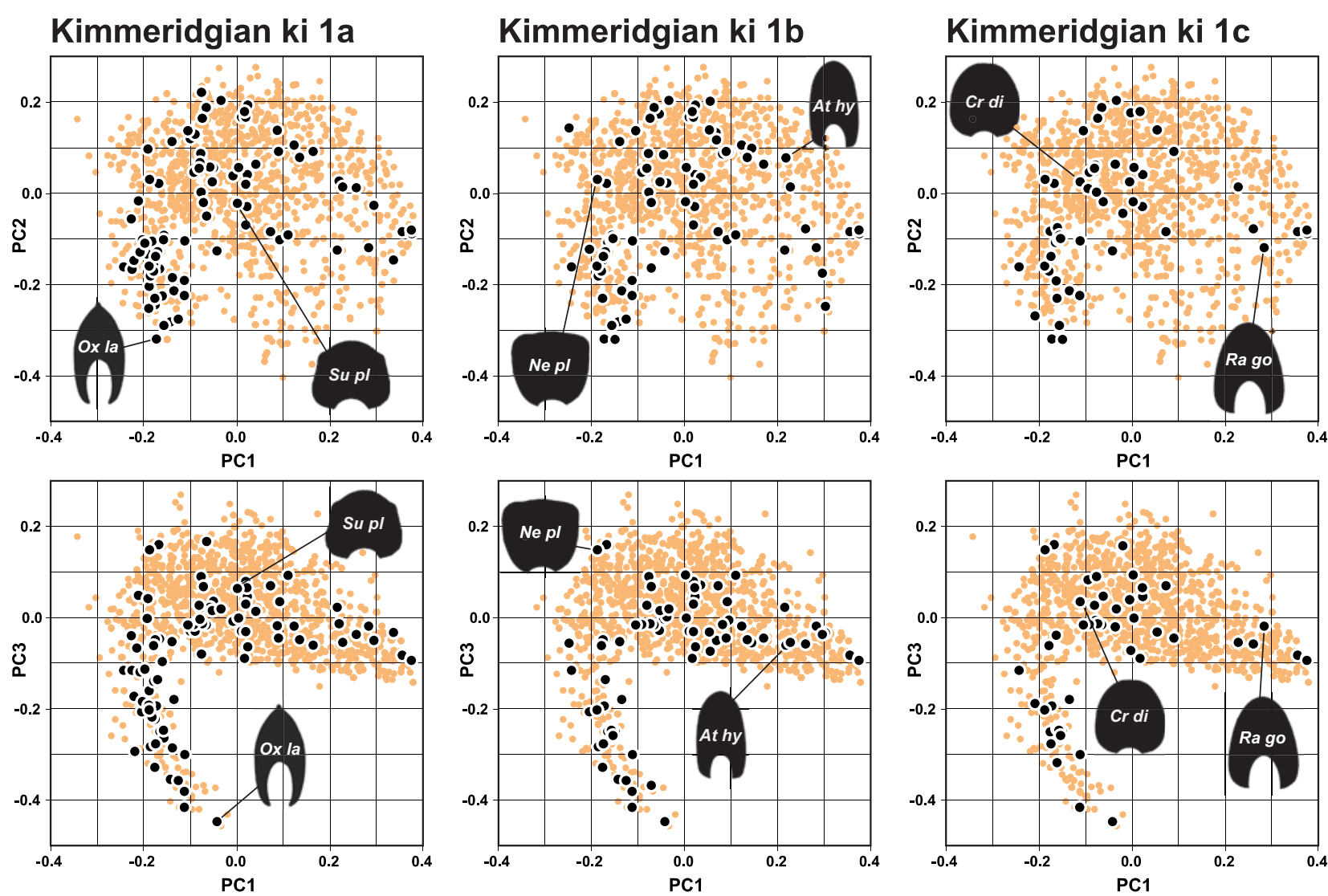

Figure 12. Morphospace development between the three successive zones ki 1a, ki 1b, and ki 1c from two views (PC1/PC2 upper diagrams; PC1/PC3 lower diagrams) with the overall morphospace in the background. Whorl outlines with representative shapes are pictured as well. Abbreviations: $\mathbf{A t} \mathbf{h y}=$ Ataxioceras hypselocyclum, $\mathbf{C r} \mathbf{d i}=$ Crussoliceras divisum, $\mathbf{N e} \mathbf{p l}=$ Nebrodites planulacinctus, $\mathbf{O x} \mathbf{l a}=$ Oxydiscites laffoni, $\mathbf{R a} \mathbf{g o}=$ Rasenia gothica, $\mathbf{S u} \mathbf{p l}=$ Sutneria platynota.

throughout most of the Late Jurassic parallels the sea level regression described by Geyer \& Gwinner (1986).

\section{Summary}

The analysis of 1,200 ammonoid species from southern Germany yields a detailed morphospace that provides the expression of disparity measures like SOR and SOV as well as the changes of the scatter plots in a chronological order. The SOV is, compared to the SOR, stable with regard to the sample size, which makes it an excellent tool for disparity analyses. However, subsampling reveals that standardized data does not provide accurate results. An interpretation of the data can therefore merely be made with non-standardized values.

Examination of the morphospace, split up into the three epochs, provides three different scatter plots with respective characteristics. A comparison of disparity and diversity shows that correlation is limited, despite the similar progression throughout the first stages of the Early Jurassic. Here, two major processes can be detected that affect both diversity and disparity in the same way; a sudden decrease in the Sinemurian and the subsequent strong increase in the early Pliensbachian indicate environmental disturbances.
A correlation can be found between sea level change and variation in diversity. Major changes of diversity occur several times during the Jurassic; the BathonianCallovian transition is characterised particularly by a markedly sudden increase of diversity. The patterns of SOV and SOR indicate migration activities. The occurrence of boreal ammonoids in the early Callovian supports this hypothesis.

Diversity data of the Late Jurassic indicate some disturbances that, however, can only be regarded as nonselective in most cases because of merely minor changes in disparity values. The final decrease of diversity and disparity could be the result of a preceding regression at the end of the Jurassic.

Two postulated mass extinctions in the early Toarcian and in the late Tithonian, respectively, can neither be accepted nor rejected. Though ammonoid faunas did not seem to be affected by the first event it is possible that benthic organisms suffered even more from disadvantageous environmental conditions. The second event is not detectable in disparity and diversity because of missing data for the entire late Tithonian. However, decreasing values since the early Kimmeridgian allow the assumption of a final event (most likely a regression) that drastically decreased ammonoid diversity in southern Germany. 


\section{Acknowledgements}

We wish to thank Susanne Zuther (Berlin) for the technical aid in data collection and processing and Sonny Walton (Potsdam) for discussing the typescript. We greatly acknowledge Al McGowan (Glasgow) and Pascal Neige (Dijon) for the review of the manuscript.

\section{References}

Aberhan, M. \& Fürsich, F. T. 1996. Diversity analysis of Lower Jurassic bivalves of the Andean Basin and the Pliensbachian-Toarcian mass extinction. - Lethaia 29: 181-195.

Aberhan, M. \& Baumiller, T. K. 2003. Selective extinction among Early Jurassic bivalves: A consequence of anoxia. - Geology 31 (12): 1077-1080

Adams, D. C., Rohlf, F. J. \& Slice, D. E. 2004. Geometric Morphometrics: Ten Years of Progress Following the 'Revolution'. - Italian Journal of Zoology 71: 5-16.

Bookstein, F. L. 1991. Morphometric tools for landmark data: Geometry and Biology. Cambridge University Press, Cambridge.

Bookstein, F. L. 1998. A hundred years of morphometrics. - Acta Zoologica Academiae Scientiarum Hungaricae 44 (1-2): 7-59.

Buckman, S. S. 1887-1907. A Monograph of the Ammonites of the Inferior Oolite Series. Palaeontographical Society London, London.

Cecca, F. \& Macchioni, F. 2004. The two early Toarcian (Early Jurassic) extinction events in ammonoids. - Lethaia 37: 35-56.

Courville, P. \& Crônier, C. 2005. Diversity or disparity in the Jurassic (Upper Callovian) genus Kosmoceras (Ammonitina): A morphometric approach. - Journal of Paleontology 79 (5): 944-953.

Crampton, J. S. \& Haines, H. S. 1996. Users' manual for programs HANGLE, HMATCH and HCURVE for the Fourier Shape analysis of two-dimensional outlines. Institute of Geological \& Nuclear Sciences Science Report (37/96), Lower Hutt.

Dean, W. T., Donovan, D. T. \& Howarth, M. K. 1961. The Liassic ammonite zones and subzones of the North-West European province. - Bulletin of the British Museum (Natural History), Geology series 4: 437-505.

Dera, G., Neige, P., Dommergues, J.-L., Fara, E., Laffont, R. \& Pellenard, P. 2010. High-resolution dynamics of Early Jurassic marine extinctions: the case of Pliensbachian-Toarcian ammonites (Cephalopoda). - Journal of the Geological Society, London 167: 21-33.

Dommergues, J.-L., Laurin, B. \& Meister, C. 1996. Evolution of ammonoid morphospace during the Early Jurassic radiation. - Paleobiology 22: 219-240.

Dommergues, J.-L., Laurin, B. \& Meister, C. 2001. The recovery and radiation of Early Jurassic ammonoids: morphologic versus palaeobiogeographical patterns. - Palaeogeography, Palaeoclimatology, Palaeoecology 165: 195-213.

Dommergues, J.-L., Montuire, S. \& Neige, P. 2002. Size patterns through time: the case of the Early Jurassic radiation. - Paleobiology 28: 423-434.

Dromart, G., Garcia, J.-P., Picard, S., Atrops, F., Lécuyer, C. \& Sheppard, S. M. F. 2003. Ice age at the Middle-Late Jurassic transition? - Earth and Planetary Science Letters 213: 205-220.

Eldredge, N. \& Gould, S. J. 1972. Punctuated equilibria: An alternative to phyletic gradualism. - In Schopf, T. J. M. (ed.). Models in Paleobiology. Freeman, Cooper and Company, San Francisco: pp. 82-115.

Ferson, S., Rohlf, F. J. \& Koehn, R. K. 1985. Measuring shape variation of two-dimensional outlines. - Systematic Zoology 34 (1): 59-68.

Foote, M. 1989. Perimeter-based Fourier Analysis: A new Morphometric Method applied to the Trilobite Cranidium. - Journal of Paleontology 63 (6): 880-885.
Foote, M. 1993. Discordance and concordance between morphological and taxonomic diversity. - Paleobiology 19 (2): 185-204.

Geyer, O. F. \& Gwinner, M. P. 1986. Geologie von Baden-Württemberg. (3. Aufl.). Schweizerbart, Stuttgart.

Gradstein, F. M. \& Ogg, J. G. 2004. Geologic Time Scale 2004 why, how, and where next! - Lethaia 37: 175-181.

Hallam, A. 1971. Provinciality in Jurassic faunas in relation to facies and palaeogeography In Middlemiss, F. A., Rawson, P. F. \& Newall, G. (eds). Faunal provinces in space and time. Geological Journal Special Issue 4. Seel House, Liverpool: pp. 129-152.

Hallam, A. 1986. The Pliensbachian and Tithonian extinction events. - Nature 319: 765-768.

Hallam, A. 1993. Jurassic climates as inferred from the sedimentary and fossil record. - Philosophical Transactions of the Royal Society B, London 341: 287-296.

Hallam, A. 1996. Recovery of the marine fauna in Europe after the end-Triassic and early Toarcian mass extinctions. - Geological Society, London, Special Publications 102: 231-236.

Hallam, A. 1997. Estimates of the amount and rate of sea-level change across the Rhaetian-Hettangian and Pliensbachian-Toarcian boundaries (latest Triassic to early Jurassic). - Journal of the Geological Society, London 154: 773-779.

Hallam, A. 1998. The determination of Jurassic environments using palaeoecological methods. - Bulletin de la Societé Géologique de France 5: 681-687.

Hallam, A. 2001. A review of the broad pattern of Jurassic sea-level changes and their possible causes in the light of current knowledge. - Palaeogeography, Palaeoclimatology, Palaeoecology 167: 23-37.

Hallam, A. \& Wignall, P. B. 1997. Mass extinctions and their aftermath. Oxford University Press, Oxford.

Hammer, O., Harper, D. A. T. \& Ryan, P. D. 2008. PAST - Palaeontological Statistics, ver. 1.77. - http://folk.uio.no/ohammer/past/ past.pdf (11/02/2008).

Irving, E. 1964. Paleomagnetism. John Wiley \& Sons, New York.

Kuhn, O. 1953. Palaeogeographie des deutschen Jura. Gustav Fischer, Jena.

Moyne S. \& Neige, P. 2007. The space-time relationship of taxonomic diversity and morphological disparity in the Middle Jurassic ammonite radiation. - Palaeogeography, Palaeoclimatology, Palaeoecology 248: 82-95.

Navarro, N., Neige, P. \& Marchand, D. 2005. Faunal invasions as a source of morphological constraints and innovations? The diversification of the early Cardioceratidae (Ammonoidea; Middle Jurassic). - Paleobiology 31 (1): 98-116.

Neige, P., Marchand, D. \& Bonnot, A. 1997. Ammonoid morphological signal versus sea-level changes. - Geological Magazine 134 (2): 261-264.

Neige, P., Elmi, S. \& Rulleau, L. 2001. Crisis - What crisis? Quantification of the morphological disparity of ammonites at the LiasDogger boundary. - Bulletin de la Societé Géologique de France 172 (2): 257-264.

Oppel, A. 1865. Die tithonische Etage. - Zeitschrift der Deutschen geologischen Gesellschaft 17: 535-558.

Quenstedt, F. A. 1885. Die Ammoniten des schwäbischen Jura Band I: Der Schwarze Jura (Lias). Stuttgart.

Quenstedt, F. A. 1886. Die Ammoniten des schwäbischen Jura Band II: Der Braune Jura. Stuttgart.

Quenstedt, F. A. 1888. Die Ammoniten des schwäbischen Jura Band III: Der Weiße Jura. Stuttgart.

Raup, D. M. \& Sepkoski, J. J. 1982. Mass extinctions in the marine fossil record. - Science 215 (4539): 1501-1503.

Rohlf, F. J. 2004. tpsdig. - http://life.bio.sunysb.edu/morph/index.html $(21 / 11 / 2007)$.

Rohlf, F. J. \& Marcus L. F. 1993. A revolution in morphometrics. Trends in Ecology \& Evolution 8 (4): 129-132.

Schlegelmilch, R. 1985. Die Ammoniten des süddeutschen Doggers. Gustav Fischer, Stuttgart \& New York. 
Schlegelmilch, R. 1992. Die Ammoniten des süddeutschen Lias (2. Aufl.). Gustav Fischer, Stuttgart, Jena \& New York.

Schlegelmilch, R. 1994. Die Ammoniten des süddeutschen Malms. Gustav Fischer, Stuttgart, Jena \& New York.

Simon, M. S., Korn, D. \& Koenemann, S. 2010. Disparity fluctuations in Jurassic ammonoids by means of conch geometry. - Palaeogeography, Palaeoclimatology, Palaeoecology 292: 520-531.

Thierry J. 2003. Ammonites of the Bathonian-Callovian of the Boulonnais: Biodiversity, biostratigraphy and biogeography. - Geobios 36 (1): 93-126.
Thompson, D. W. 1917. On Growth and Form. Cambridge University Press, Cambridge.

Walter, R. 1992. Geologie von Mitteleuropa (5. Aufl.). Schweizerbart, Stuttgart.

Wills, M. A. 2001. Morphological disparity: A primer. In Adrain, J. M., Edgecombe, G. D. \& Lieberman, B. S. (eds). Fossils, Phylogeny, and Form - An analytical approach. Topics in Geobiology 19. Plenum, New York: pp. 55-144.

Wills, M. A., Briggs, D. E. G. \& Fortey R. A. 1994. Disparity as an evolutionary index - A comparison of Cambrian and Recent arthropods. - Paleobiology 20 (2): 93-130. 